\title{
Inter-Kingdom Signaling of Stress Hormones: Sensing, Transport and Modulation of Bacterial Physiology
}

OPEN ACCESS

Edited by:

Qi Zhao,

University of Science and Technology Liaoning, China

Reviewed by:

Ting Qin,

Freshwater Fisheries Research Center, Chinese Academy of Fishery Sciences, China

Balbina J. Plotkin,

Midwestern University, United States

*Correspondence:

Nathalie Conn

nathalie.connil@univ-rouen.fr

${ }^{\dagger}$ These authors have contributed equally to this work

Specialty section:

This article was submitted to Systems Microbiology, a section of the journal

Frontiers in Microbiology

Received: 04 April 2021 Accepted: 06 August 2021

Published: 06 October 2021

Citation:

Boukerb AM, Cambronel M

Rodrigues S, Mesguida O,

Knowiton R, Feuilloley MGJ, Zommiti M and Connil N (2021) Inter-Kingdom Signaling of Stress

Hormones: Sensing, Transport and Modulation of Bacterial

Physiology.

Front. Microbiol. 12:690942. doi: 10.3389/fmicb.2021.690942
Amine Mohamed Boukerb ${ }^{1+}$, Melyssa Cambronel'1+, Sophie Rodrigues ${ }^{2}$, Ouiza Mesguida ${ }^{1}$, Rikki Knowlton ${ }^{3}$, Marc G. J. Feuilloley ${ }^{1}$, Mohamed Zommiti ${ }^{1}$ and Nathalie Connil ${ }^{1 *}$

'Laboratoire de Microbiologie Signaux et Microenvironnement EA 4312, Université de Rouen, Normandie Université, Évreux, France, ${ }^{2}$ EA 3884, LBCM, IUEM, Université de Bretagne-Sud, Lorient, France, ${ }^{3}$ MRC Laboratory of Molecular Biology,

Cambridge, United Kingdom

Prokaryotes and eukaryotes have coexisted for millions of years. The hormonal communication between microorganisms and their hosts, dubbed inter-kingdom signaling, is a recent field of research. Eukaryotic signals such as hormones, neurotransmitters or immune system molecules have been shown to modulate bacterial physiology. Among them, catecholamines hormones epinephrine/norepinephrine, released during stress and physical effort, or used therapeutically as inotropes have been described to affect bacterial behaviors (i.e., motility, biofilm formation, virulence) of various Gram-negative bacteria (e.g., Escherichia coli, Salmonella enterica serovar Typhimurium, Pseudomonas aeruginosa, Vibrio sp.). More recently, these molecules were also shown to influence the physiology of some Gram-positive bacteria like Enterococcus faecalis. In E. coli and S. enterica, the stress-associated mammalian hormones epinephrine and norepinephrine trigger a signaling cascade by interacting with the QseC histidine sensor kinase protein. No catecholamine sensors have been well described yet in other bacteria. This review aims to provide an up to date report on catecholamine sensors in eukaryotes and prokaryotes, their transport, and known effects on bacteria.

Keywords: stress hormones, catecholamines, sensing, transport, bacterial physiology

\section{INTRODUCTION}

Stress is a complex event that impacts the homeostasis of the whole organism. In cases of stress, the concentration/release of stress hormones/catecholamines may be raised by $20-40$ times the physiological values and can reach $0.17-0.54 \mu \mathrm{g}$ per minute. In some organs, such as the spleen or the gut, they can lead to local concentrations of up to 0.1-1 mM (Felten and Olschowka, 1987; Bergquist et al., 1998). This is caused by discharge from synaptic vesicles at noradrenergic nerve endings. Catecholamines (dopamine, norepinephrine, and epinephrine) are found throughout the plant and animal kingdoms (Akula and Mukherjee, 2020). In mammals, they can stimulate lipolysis and glycogenolysis and mobilize energy more rapidly than cortisol, as the latter's activity requires transcription of genes.

Catecholamines are organic nitrogen compounds derived from the amino acid L-tyrosine (Figure 1). The first step in the biosynthesis of these molecules is the hydroxylation of L-tyrosine 


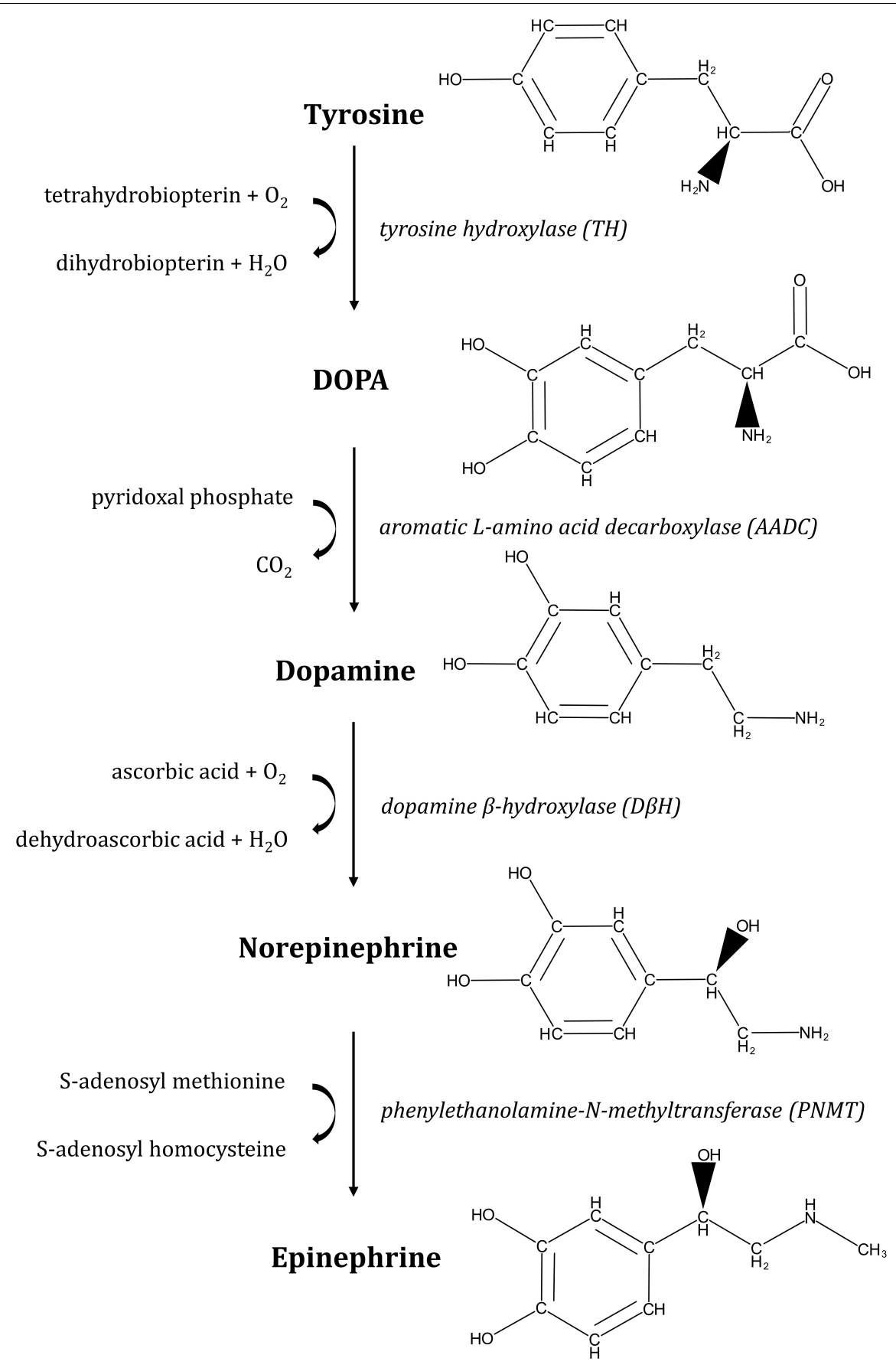

FIGURE 1 | Pathway of epinephrine and norepinephrine biosynthesis. Synthesis of catecholamines starts with conversion of L-tyrosine to L-dopa by tyrosine hydroxylase $(\mathrm{TH})$. Then, $\mathrm{L}$-dopa is processed to dopamine by $\mathrm{L}$-aromatic amino acid decarboxylase (AADC), from where norepinephrine is formed by dopamine- $\beta$-hydroxylase $(\mathrm{D} \beta \mathrm{H})$. Finally, epinephrine is synthesized by addition of a methyl group to norepinephrine by phenylethanolamine- $N$-methyltransferase (PNMT). In mammals, catecholamines are synthesized from L-Dopa, obtained from dietary sources (the amino acids tyrosine and phenylalanine).

to L-dopa (L-dihydroxy-phenylalanine) by tyrosine hydroxylase. L-dopa is then decarboxylated to dopamine by Dopadecarboxylase. This hormone is successively converted to norepinephrine (NE) and then epinephrine (Epi) by dopamine $\beta$-hydroxylase and phenylethanolamine- $N$-methyltransferase, respectively.
Intestinal expression of tyrosine hydroxylase was found upregulated in response to surgical perforation of the bowel and gut-derived sepsis in rats (Zhou et al., 2004). Subsequently, high levels of NE were detected in their fecal pellets. Catecholamines can act as hormones or neurotransmitters. They are synthesized by the cells of the adrenal medulla and by the postganglion 
neurons of the orthosympathetic nervous system. Epi acts as a neurotransmitter in the central nervous system and as a hormone in the bloodstream. NE is primarily a neurotransmitter in the peripheral sympathetic nervous system but is also found in the blood. Dopamine is an essential neurotransmitter in the motivation and reward system.

In the human body, catecholamines act on almost all tissues and exert numerous activities at the cardiovascular, metabolic, endocrine, and neuronal levels. They also affect the intestinal barrier and immunity (Lymperopoulos et al., 2008). The action of catecholamines takes place after binding to specific receptors located on the cell membranes of target tissues: the $\alpha$ - and $\beta$-adrenergic receptors. The effects of catecholamines have long been studied only in humans without considering their possible impact on the microbiota. However, prokaryotes and eukaryotes have been intimately cohabiting for a very long time. In the gut and other tissues with contact to the external world via epithelial surfaces, catecholamines can cross the epithelial border and interact with microorganisms living in those ecological niches. In the colon, NE can reach a concentration of about $50 \mathrm{ng} / \mathrm{g}$ luminal content. Thus, bacteria have been in contact with the host hormones and have been able to develop complex interactions. In 1992, Lyte and Ernst were the pioneers who evaluated the effects of stress hormones on bacterial growth and introduced for the first time the concept of microbial endocrinology, a bi-directional interaction between human neuroendocrine factors and microorganisms (Lyte and Ernst, 1992; Sharaff and Freestone, 2011). It was subsequently shown that Epi/NE stimulates the growth of Gram-negative enteric pathogens of various genera (e.g., Salmonella, Shigella, Yersinia, Vibrio, and Campylobacter) as well as pathotypes of E. coli such as EHEC (Enterohemorrhagic E. coli) and ETEC (Enterotoxigenic E. coli). This new concept may help to understand how stress influences susceptibility to infection (Freestone et al., 2008). Since then, many studies have shown that catecholamines can have various stimulating effects on numerous Gram-negative and Gram-positive bacterial pathogens (i.e., growth, motility, biofilm formation, adhesion, cytotoxicity/virulence), and sensor systems allowing to perceive these molecules have been discovered for some bacterial species.

\section{SENSING OF CATECHOLAMINES}

\section{Eukaryotic (Human) Sensors of Catecholamines: Adrenergic Receptors}

Pharmacological classification of adrenergic receptors (AR) as $\alpha$ - and $\beta$-adrenergic receptors (Table 1) was first described in 1948 (Ahlquist, 1948). This classification was established according to their pharmacological properties and physiological effects (Perez, 2006). The $\alpha$-adrenergic receptors are mainly involved in excitatory functions (vasoconstriction, uterine contraction, contraction of the nictitating membrane, pupillary dilation) whereas $\beta$-receptors are more commonly related to inhibitory responses (vasodilatation, inhibition of uterine contraction, myocardial stimulation). The $\alpha$-receptor group is subdivided in two sub-groups: $\alpha-1$ and $\alpha-2$ (Berthelsen and
Pettinger, 1977). Each of them is composed of three subtypes, $\alpha-1 \mathrm{~A}, \alpha-1 \mathrm{~B}$, and $\alpha-1 \mathrm{D}$ (Ford et al., 1994), or $\alpha-2 \mathrm{~A} / \mathrm{D}, \alpha-2 \mathrm{~B}$, and $\alpha-2 \mathrm{C}$ (Bylund, 1988; Hieble et al., 1995). $\beta$-receptors are also subdivided in three subtypes: $\beta-1, \beta-2$, and $\beta-3$ (Lands et al., 1967a,b; Emorine et al., 1989). The first cloned and characterized drug receptor was the $\beta-2$ AR (ADRB2) that binds Epi (Dixon et al., 1986). NE has relatively higher binding affinity for $\alpha$ - ARs and $\beta-1 / 3$ ARs, but a lower affinity for $\beta-2$ AR. All these receptors belong to the group of $G$ Protein-Coupled Receptors (GPCRs), the largest family of cell-surface proteins involved in signal transduction (Rosenbaum et al., 2009). They

TABLE 1 | Adrenergic receptors and physiological effects.

\begin{tabular}{|c|c|c|c|c|}
\hline Subtypes & $\begin{array}{c}\text { G } \\
\text { proteins }\end{array}$ & $\begin{array}{l}\text { Intracellular } \\
\text { messengers }\end{array}$ & Target organs & $\begin{array}{l}\text { Physiological } \\
\text { effects }\end{array}$ \\
\hline \multirow[t]{7}{*}{$\alpha 1$} & \multirow[t]{7}{*}{$\mathrm{Gq}$} & \multirow{7}{*}{$\begin{array}{l}\text { Increase in } \\
\text { PLC and IP3 }\end{array}$} & Uterine & Contraction \\
\hline & & & $\begin{array}{l}\text { Vascular smooth } \\
\text { muscles }\end{array}$ & Contraction \\
\hline & & & Blood vessels & Constriction \\
\hline & & & Gl sphincter & Increase in tone \\
\hline & & & Urinary sphincter & Increase in tone \\
\hline & & & $\begin{array}{l}\text { Pupillary radial } \\
\text { muscle }\end{array}$ & $\begin{array}{l}\text { Contraction } \\
\text { (mydriasis) }\end{array}$ \\
\hline & & & $\begin{array}{l}\text { Pilomotor smooth } \\
\text { muscle }\end{array}$ & $\begin{array}{l}\text { Contracts (erects } \\
\text { hair) }\end{array}$ \\
\hline \multirow[t]{7}{*}{$\alpha 2$} & \multirow[t]{7}{*}{ Gi } & \multirow{7}{*}{$\begin{array}{l}\text { Decrease in } \\
\text { CAMP }\end{array}$} & Presynaptic nerves & \\
\hline & & & $\begin{array}{l}\text { Adrenergic and } \\
\text { cholinergic } \\
\text { nerves terminals }\end{array}$ & $\begin{array}{l}\text { Inhibit transmitter } \\
\text { release }\end{array}$ \\
\hline & & & Platelets & Stimulate aggregation \\
\hline & & & $\begin{array}{l}\text { Some vascular } \\
\text { smooth muscle }\end{array}$ & Contraction \\
\hline & & & Fat cells & Inhibit lipolysis \\
\hline & & & Pancreatic B cells & Inhibit insuline release \\
\hline & & & Ciliary epithelium & $\begin{array}{l}\text { Reduction of humor } \\
\text { secretion }\end{array}$ \\
\hline \multirow[t]{2}{*}{$\beta 1$} & \multirow[t]{2}{*}{ Gs } & \multirow[t]{2}{*}{$\begin{array}{l}\text { Increase in } \\
\text { cAMP }\end{array}$} & Heart & $\begin{array}{l}\text { Stimulates rate and } \\
\text { force }\end{array}$ \\
\hline & & & Kidney & $\begin{array}{l}\text { Stimulates renin } \\
\text { release }\end{array}$ \\
\hline \multirow[t]{7}{*}{$\beta 2$} & \multirow[t]{7}{*}{ Gs } & \multirow[t]{7}{*}{$\begin{array}{l}\text { Increase in } \\
\text { cAMP }\end{array}$} & Liver & $\begin{array}{l}\text { Stimulates } \\
\text { glycogenolysis }\end{array}$ \\
\hline & & & Pancreatic B cells & $\begin{array}{l}\text { Stimulates insulin } \\
\text { release }\end{array}$ \\
\hline & & & Skeletal muscle & Contraction \\
\hline & & & Heart & $\begin{array}{l}\text { Stimulates rate and } \\
\text { force }\end{array}$ \\
\hline & & & Ciliary epithelium & $\begin{array}{l}\text { Increases of humor } \\
\text { secretion }\end{array}$ \\
\hline & & & $\begin{array}{l}\text { Airways, uterine } \\
\text { and vascular } \\
\text { smooth muscle }\end{array}$ & Relaxes \\
\hline & & & Uterine & Inhibit contraction \\
\hline$\beta 3$ & Gs & $\begin{array}{l}\text { Increase in } \\
\text { cAMP }\end{array}$ & $\begin{array}{l}\text { Adipose tissues } \\
\text { (Fat cells) }\end{array}$ & Stimulates lipolysis \\
\hline
\end{tabular}


contain seven transmembrane domains (Strosberg, 1993), and are linked to a GTP-binding regulatory $G$ protein. The $G$ protein is composed of three subunits: $\alpha, \beta$, and $\gamma$. The $\alpha$ subunit determines the signal transduction pathway which will modulate the activity of second messengers (Marinissen and Gutkind, 2001). Generally, $\mathrm{G}$ proteins can be divided into $\mathrm{Gi}$, Gs, Gq/11, and G12/13 subfamilies according to their $\alpha$ subunits. Catecholamine receptors have been defined using highly selective receptor agonists and antagonists in functional pharmacological investigations, delivering information on their affinities $(\mathrm{Kd}$, dissociation constant). However, such studies do not reflect the biological activity of the ligand-receptor interaction, which is an entity functionally coupled to intracellular signal transduction pathways. Thus, new strategies are now used on isolated cells and transgenic animals based on molecular cloning and structure-function analysis to encounter such limitations, providing precious data on selective antagonism, rank order of ligand potency and stereospecificity. Catecholamines activate various cellular signal transduction by binding to these receptors, activating the $\mathrm{G}$ proteins which can then modulate effectors such as adenylate cyclase or phospholipase C (PLC) (Figure 2). The $\alpha 1$-receptor is coupled with $\mathrm{G}_{q}$ protein, allowing activation of kinase protein $\mathrm{C}$ (PKC) and increase of intracellular concentration of $\mathrm{Ca}^{2+}$, through the triphosphate inositol (IP3)/diacylglycerol (DAG) pathway. Activation of this pathway results from the cleavage of phosphatidylinositol-4,5bisphosphate (PIP2) in IP3 and DAG thanks to phospholipase C (PLC). $\alpha-2$ and $\beta$-receptors are coupled to $G_{i}$ and $G_{s}$, respectively. In both cases, cAMP (cyclic adenosine monophosphate) is increased or decreased depending on the stimulation $\left(G_{s}\right)$ or inhibition $\left(\mathrm{G}_{i}\right)$ of adenylate cyclase $(\mathrm{AC})$, leading to the activation of kinase protein A (PKA). Variations in the concentrations of the intracellular secondary messengers lead to physiological modifications (e.g., vasoconstriction, uterine contraction or pupillary dilatation) (Table $\mathbf{1}$ ).

Several antagonists can bind to the adrenergic receptors with a high affinity, and competitively block the effects of ligands. For example, $\alpha-1$ and $\beta$ receptors can be respectively inhibited by phentolamine and propranolol. The latter is used in medical settings for hypertension as a $\beta$-blocker with an antihypertensive role (Lewis, 1976).

\section{Prokaryotic Sensors of Catecholamines}

As aforementioned, the study of microbiota response to eukaryotic signaling molecules and resulting behavior of the host is known as microbial endocrinology, highlighted by Lyte and Ernst (1992), but first evidence of interaction between bacterial pathogens and the host were described as early as 1930 (Renaud and Miget, 1930) when the syringe used to inject Epi was not correctly sterilized, leading to gas gangrene. A similar case was also described by Cooper (1946). Following these discoveries, many studies were carried out to understand the effect of Epi on bacteria. Various physiological effects of catecholamines were observed (see below) and sometimes the presence of a bacterial sensor for these molecules has been proposed.

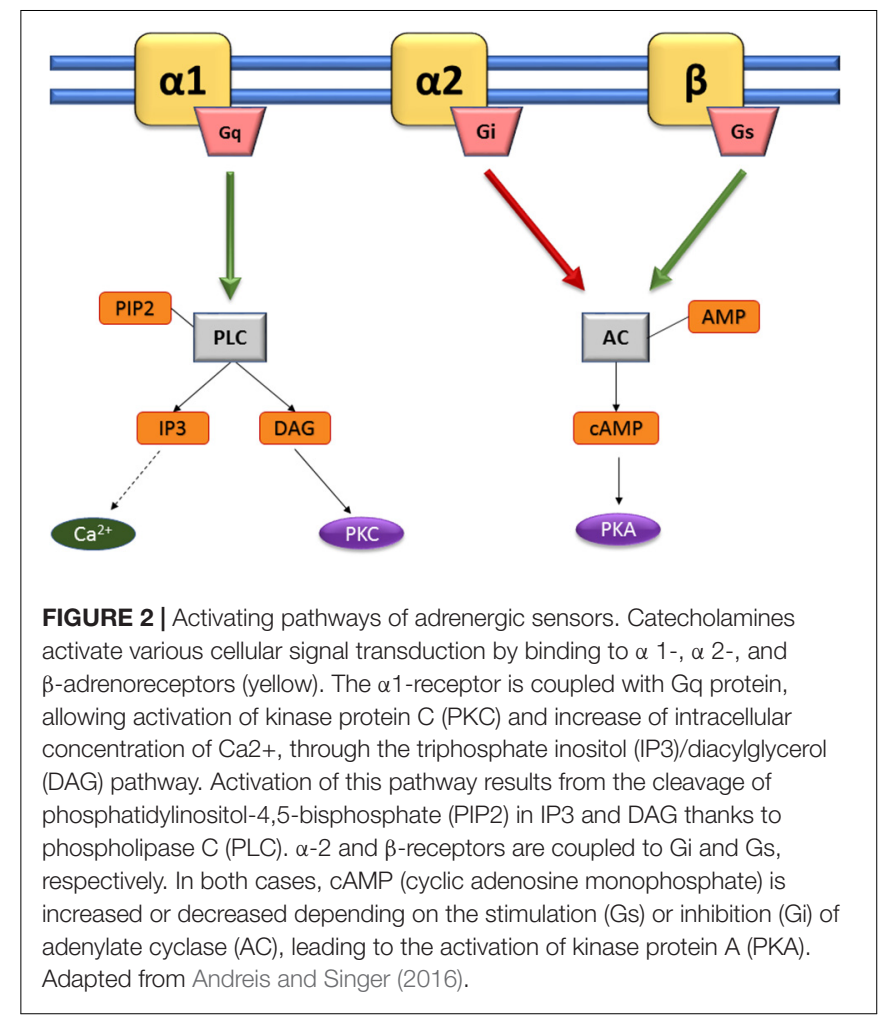

The main signaling transduction systems in bacteria are the two-component systems. In these systems, the sensor for environmental cues is a histidine kinase, which upon autophosphorylation transfers its phosphate to an aspartate residue in the response regulator, which is usually a transcription factor that is activated by phosphorylation. Clarke et al. (2006) showed that the QseC sensor kinase is a bacterial receptor for the host Epi/NE (Figure 3). QseC is part of the QseBC system, initially described as a two-component system regulated by quorum sensing and involved in regulation of flagella and motility in EHEC. Sperandio et al. (2003) showed that Epi was sensed by EHEC serotype O157:H7 via QseC, and activated EHEC virulence regulators like ler, the regulator of the Locus of Enterocyte Effacement (LEE) which is a pathogenicity island that contains 41 genes. Most of them are organized in five major operons, coding for a type III secretion system (responsible for attaching and effacement lesion in the large intestine cells), in addition to an adhesin (intimin) and its receptor. QseC was found to activate the LEE operons through $\mathrm{KdpE}$ and QseFregulated sRNAs, and suggested to be the sensor for LuxSdependent autoinducer-3 (AI-3) and Epi (Figure 3). Rasko et al. (2008) showed that exposure of EHEC strain 86-24 to $50 \mu \mathrm{M}$ Epi increased the expression of the ler gene by 1.5fold. Recently, the description of the complete structure of AI-3 uncovered the most active molecule within AI-3 family being a new pyrazinone-type of metabolite (Kim et al., 2020). QseC possesses a periplasmic domain with a sensor domain, two transmembrane domains and a kinase domain, while the response regulator $\mathrm{QseB}$ contains a receptor domain as well as a helix-turn-helix (HTH) domain. Activation of QseC 


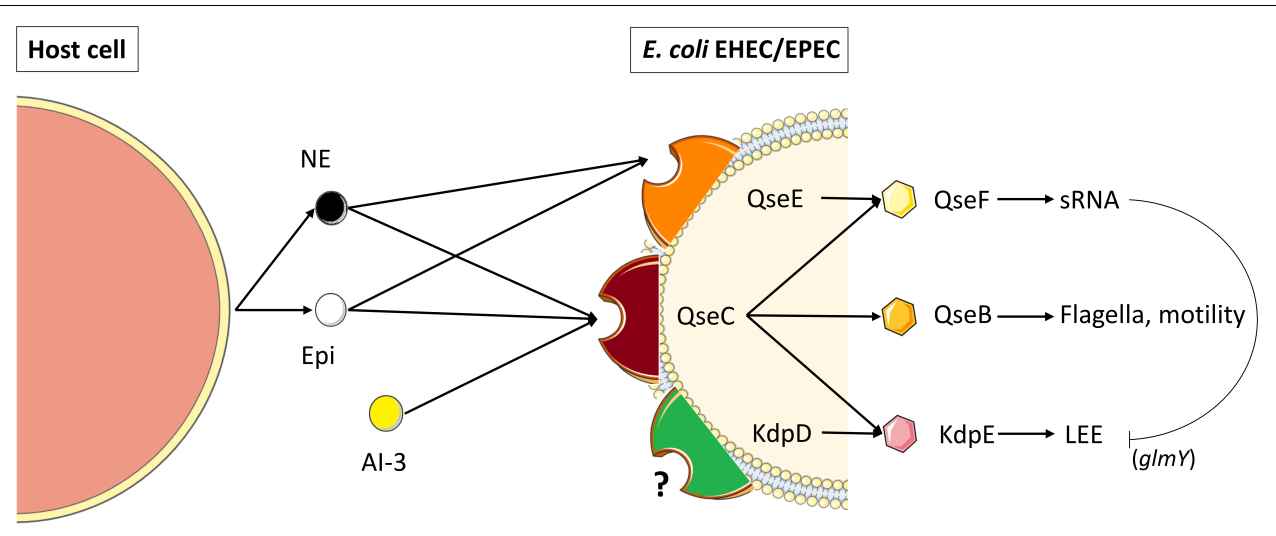

FIGURE 3 | Catecholamine sensing and signal transduction in enterohemorrhagic and enteropathogenic E. coli (EHEC/EPEC). QseC is an adrenergic sensor kinase that autophosphorylates on detection of NE, Epi and Al-3 and transfers the phosphate moiety to its cognate response regulator QseB, thereby activating transcription of the flagellar regulon (Clarke et al., 2006). Transcription of genes encoding a second two-component system (QseEF) is sensitive to NE and Epi and is implicated in small RNAs expression (Reading et al., 2009). Kinase activity in QseC is promiscuous and can activate two additional non-cognate response regulators, KdpE and QseF. QseC also activates the locus of enterocyte effacement (LEE), through KdpE, which is inhibited through sRNAs ( $g / m Y$ ) that are modulated by QseF. (Adapted from Ellermann and Sperandio, 2020). KdpD, a transmembrane protein showing partial homology with QseC may also act as a catecholamine receptor (Borrel et al., 2019).

leads to the transfer of phosphate to the response regulator QseB, which then regulates its own transcription, as well as the transcription of flagella and motility genes (Clarke and Sperandio, 2005a,b). In addition, an osmosensitive $\mathrm{K}^{+}$ channel histidine kinase, named $\mathrm{KdpD}$, was found sharing partial homology with QseC, suggesting its possible role as a catecholamine receptor, which needs to be elucidated (Figure 3). Multiple studies using E. coli EHEC and UPEC (uropathogenic) isolates have demonstrated that $q s e C$ mutants have decreased motility (Sperandio et al., 2003; Hughes et al., 2009; Kostakioti et al., 2009; Hadjifrangiskou et al., 2011; Guckes et al., 2013). An E. coli $\mathrm{O} 157: \mathrm{H} 7$ qseC mutant presented pleiotropic phenotypes including virulence attenuation, metabolic dysregulation and decreased motility (Kostakioti et al., 2009; Hadjifrangiskou et al., 2011). Interestingly, an E. coli O157:H7 qseBC mutant has a similar motility phenotype compared to wild-type O157:H7 (Sharma and Casey, 2014a,b). However, in response to $50 \mu \mathrm{M}$ $\mathrm{NE}$, they observed a significant increase in the motility of $E$. coli O157:H7 qseC and qseBC mutants. These results suggest that in addition to QseC, other regulatory systems sense and respond to Epi and NE in E. coli. As such, QseC seems to be involved in an inter-kingdom communication by sensing both bacterial quorum sensing molecules (i.e., AI-3) and hormones secreted by the host (i.e., Epi and NE). Another two-component system found in E. coli EHEC, named QseEF (Figure 3) was shown to belong to the signaling cascade Epi/NE/AI-3 (Reading et al., 2007). The transcription of $q s e E$ can be activated by the sensor QseC, after recognition of Epi. QseE can also be activated by the presence of Epi (Figure 3) but not by AI-2 or AI-3 (Reading et al., 2009). An in silico screening of the sensing-domain of QseC revealed a high degree of conservation within several bacterial species (Clarke et al., 2006), encompassing S. enterica serovar Typhimurium in which it may participate in Epi/NE signaling. Furthermore, it has been shown that in absence of $q s e C$ in this bacterium, $\mathrm{NE}$ was still able to activate the transcription of some genes, meaning that QseC is not the only sensor of Epi/NE in S. enterica serovar Typhimurium (Moreira et al., 2010). During the same period, other alternative sensor systems for Epi/NE have been described in Salmonella such as BasRS and CpxAR (Karavolos et al., 2008, 2011). To our knowledge, no other sensors for catecholamines have been described lately in bacteria, except two recent works on Cutibacterium acnes (former Propionibacterium acnes), and E. faecalis suggesting the role of $\mathrm{KdpD}$ and VicK (WalK), respectively, as putative adrenergic receptors (Borrel et al., 2019; Cambronel et al., 2020). The latter authors identified VicK as the closest protein to QseC with $29 \%$ identity and $46 \%$ similarity values. Structure modeling and molecular docking of VicK corroborated its possible interactions with Epi and NE, with binding energies of -4.08 and $-4.49 \mathrm{kcal} / \mathrm{mol}$, respectively.

Eukaryotic adrenergic antagonists were used in some studies and found to be able to block the physiological effects of catecholamines in bacteria (see below). LED209 [ $N$-phenyl-4(3-phenylthioureido) benzenesulfonamide], a bacterial inhibitor of QseC has also been identified through a high-throughput screening of a library of 150,000 small organic compounds and subsequent lead optimization (Rasko et al., 2008). This inhibitor has a unique mode of action by acting as a prodrug scaffold to deliver a warhead that allosterically modifies QseC, impeding virulence in several Gram-negative pathogens (Curtis et al., 2014).

\section{TRANSPORT OF CATECHOLAMINES}

\section{Transport in Eukaryotes}

The monoamines, including the catecholamines (Epi, NE, dopamine), are a group of important neurotransmitters and neurohormones (Duan and Wang, 2010) that regulates a wide array of physiological, behavioral, cognitive, and endocrine functions in central and peripheral nervous 
systems (Carlsson, 1987; Greengard, 2001). The actions of released monoamine neurotransmitters are terminated by plasma membrane transporters that actively remove them from the extracellular space (Duan and Wang, 2010). Two distinct transport systems, named uptake1 and uptake2, are responsible for the clearance of monoamines in eukaryotic cells (Gründemann et al., 1998; Eisenhofer, 2001). Uptake1 consists of $\mathrm{Na}^{+}$and $\mathrm{Cl}^{-}$dependent, high-affinity transporters while the uptake2 was originally characterized as a $\mathrm{Na}^{+}$and $\mathrm{Cl}^{-}$ independent, low-affinity, high-capacity transport system in peripheral tissues such as heart and smooth muscle cell (Iversen, 1971; Bönisch et al., 1985; Eisenhofer, 2001). The uptake2 system has also been found in various brain areas like cortex and striatum (Hendley et al., 1970; Wilson et al., 1988). In addition, studies on transport of monoamines in the brains, of serotonin (5-HT = 5-hydroxytryptamine), dopamine, and NE transporters knockout mice, demonstrated the existence of heterologous uptake of monoamines that cannot be exhaustively explained by the promiscuity of the abovementioned neuronal high-affinity monoamine transporters (Sora et al., 2001; Wayment et al., 2001; Moron et al., 2002). The plasma membrane monoamine transporter (PMAT) and organic cation transporter 3 (OCT3) are the two most prominent low-affinity, high-capacity (uptake2) transporters for catecholamines (Duan and Wang, 2010). These authors demonstrated that hPMAT (human plasma membrane monoamine transporter) is the major uptake2 transporter for serotonin and dopamine in the central nervous system, whereas hOCT3 (human organic cation transporter 3) represents the major uptake2 transporter for histamine, NE, and Epi in peripheral organs. The PMAT transports dopamine and serotonin with $\mathrm{Km}$ values in the high micromolar range while histamine, Epi, and NE are transported with $\mathrm{Km}$ values in the low millimolar range (Engel et al., 2004; Engel and Wang, 2005). The PMAT is widely distributed throughout the brain with the highest expression in the forebrain cortex, olfactory tubercle, hippocampus, and cerebellum (Dahlin et al., 2007; Vialou et al., 2007). PMAT expression has been detected in diverse populations of neurons including pyramidal neurons, interneurons, granular neurons, and Purkinje cells while no significant expression was measured in astroglial cells (Dahlin et al., 2007).

\section{Transport in Prokaryotes}

Information about putative entrance/transport of catecholamines in bacteria is scarce and not well understood. Lyte and Brown (2018) hypothesized that probiotics belonging to the genus Lactobacillus express uptake systems of biogenic amines, based on the observations of Yernool et al. (2004) and Yamashita et al. (2005), who demonstrated that bacterial transporters analogous to glutamate and leucine were expressed in bacteria. To test their hypothesis, Lyte and Brown have examined monoamine uptake in Lactobacillus biofilms using fluorescent probes for membrane amine transport (Lyte and Brown, 2018). The results of this study suggested that some lactobacilli biofilms express functional homologs of PMAT and OCT, which could take up and potentially deliver bioactive amines to nearby microbes or host cells in the intestinal tract. Bacterial analogs of biogenic amine transporters may contribute to the ability of the microbiota-gutbrain axis to influence brain function and ultimately behavior (Lyte, 2014; Sharon et al., 2016). It remains to be determined whether other bacterial species can express these biogenic amine transporters.

The putative conversion of catecholamines by bacteria has also been suggested (Toulouse et al., 2019; Reiske et al., 2020). Epi is converted by the pathogen $V$. cholerae to adrenochrome in the course of respiration. Superoxide produced by the respiratory $\mathrm{Na}^{+}$translocating NADH: quinone oxidoreductase (NQR) act as an electron acceptor in the oxidative conversion of Epi to adrenochrome.

\section{MODULATION OF BACTERIAL PHYSIOLOGY}

\section{Effect on Growth and Capture of Iron}

In vitro antimicrobial activity of catecholamines have been observed by Cuvas Apan et al. (2016) and Kesici et al. (2019). In fact, Cuvas Apan et al. (2016) found that saline dilutions of Epi, $\mathrm{NE}$, and dopamine at clinically used concentrations decreased microbial growth of Staphylococcus aureus, Staphylococcus epidermidis, and Candida albicans, whereas E. coli and $P$. aeruginosa were more resistant. Despite this, most of the studies that were carried out have shown that catecholamines generally had no impact on bacterial growth when the bacteria were cultivated in rich media. On the contrary, experiments performed in minimal media or in low-iron media like serumSAPI showed an increase of bacterial growth in presence of catecholamines for several bacteria (Table 2). For example, NE can enhance the growth of S. enterica serovar Typhimurium in serum-SAPI minimal medium (Freestone et al., 1999; Williams et al., 2006), suggesting that additional biosynthetic pathways would be modulated besides the iron utilization and transport genes. Using microarray-based transcriptional analysis on S. enterica serovar Typhimurium grown in serum-SAPI medium with or without $2 \mathrm{mM} \mathrm{NE}$, Bearson et al. (2008) found an increase in transcription of genes involved in amino acid biosynthesis, cofactor biosynthesis, energy metabolism, central intermediary metabolism and synthesis of transport and binding proteins. Thus, to take advantage of the increased availability of iron provided by $\mathrm{NE}$ in serum-SAPI minimal medium, $S$. enterica serovar Typhimurium modulates the biosynthesis of multiple cellular pathways to increase its growth rate. In fact, iron is an essential element for almost all organisms, as an indispensable enzymatic co-factor in many cellular processes; and most bacteria require micromolar levels of bioavailable iron for optimal growth (Ratledge and Dover, 2000). During infection, a coordinated host response limits the availability of iron to microbes and restricts the replication of invading pathogens (Ganz and Nemeth, 2015). Iron sequestration is mainly due to the mammalian ferric-iron-binding proteins transferrin in serum and lactoferrin in mucosal secretions (Mietzner and Morse, 1994). A strategy that bacteria often employ to collect essential iron is the production and utilization of siderophores, that possess high affinity for ferric iron 
TABLE 2 | Bacterial growth in presence of catecholamines.

\begin{tabular}{|c|c|c|}
\hline Gram-negative bacteria & Catecholamines & References \\
\hline $\begin{array}{l}\text { Acinetobacter Iwoffii, Citrobacter freundii, Enterobacter aerogenes, Enterobacter } \\
\text { agglomerans, Enterobacter cloacae, Enterobacter sakazaki, Escherichia coli, Hafnia alvei, } \\
\text { Klebsiella oxytoca, Klebsiella pneumoniae, Morganella morganii, Pseudomonas aeruginosa, } \\
\text { Proteus mirabilis, Salmonella enterica sv Enteritidis, Serratia marcescens, Yersinia } \\
\text { enterocolitica, Xanthomonas maltophilia }\end{array}$ & NE & $\begin{array}{l}\text { Freestone et al., 1999, 2000, } \\
\text { 2003, Freestone, } 2013\end{array}$ \\
\hline Actinobacillus pleuropneumoniae & $\begin{array}{l}\text { Epi } \\
\text { NE } \\
\text { Dopamine }\end{array}$ & Li et al., 2015 \\
\hline Aeromonas hydrophila & $\begin{array}{l}\text { Epi } \\
\text { NE } \\
\text { Dopamine }\end{array}$ & Dong et al., 2016 \\
\hline Bordetella bronchiseptica & $\mathrm{NE}$ & $\begin{array}{l}\text { Anderson and Armstrong, } 2008 \\
\text { Armstrong et al., } 2012\end{array}$ \\
\hline Burkholderia pseudomallei & Epi & Intarak et al., 2014 \\
\hline Campylobacter jejuni & $\begin{array}{l}\text { NE } \\
\text { Epi } \\
\text { NE }\end{array}$ & $\begin{array}{l}\text { Cogan et al., } 2007 \\
\text { Xu et al., } 2015\end{array}$ \\
\hline Escherichia coli & $\begin{array}{l}\text { Epi } \\
\text { NE } \\
\text { Dopamine }\end{array}$ & Burton et al., 2002 \\
\hline Pseudomonas aeruginosa PA14 & $\begin{array}{l}\text { NE } \\
\text { NE } \\
\text { Dopamine }\end{array}$ & $\begin{array}{l}\text { Hegde et al., } 2009 \\
\text { Freestone et al., } 2012\end{array}$ \\
\hline Pseudomonas fluorescens MFN1032 & NE & Biaggini et al., 2015 \\
\hline Salmonella enterica serovar Typhimurium & $\begin{array}{l}\text { NE } \\
\text { Dopamine }\end{array}$ & $\begin{array}{l}\text { Williams et al., } 2006 \\
\text { Dichtl et al., } 2019\end{array}$ \\
\hline $\begin{array}{l}\text { Vibrio parahaemolyticus, } \\
\text { Vibrio cholerae, Vibrio vulnificus, } \\
\text { Vibrio mimicus }\end{array}$ & NE & Nakano et al., 2007a \\
\hline Vibrio cholerae & $\begin{array}{l}\text { Epi } \\
\text { NE }\end{array}$ & Halang et al., 2015 \\
\hline Yersinia ruckeri & $\begin{array}{l}\mathrm{NE} \\
\text { Dopamine }\end{array}$ & Torabi Delshad et al., 2019 \\
\hline Gram-positive bacteria & Catecholamines & References \\
\hline $\begin{array}{l}\text { Enterococcus faecalis, Enterococcus faecium, Listeria monocytogenes, Staphylococcus } \\
\text { aureus, Staphylococcus epidermidis, Streptococcus dysgalactiae } \\
\text { Listeria monocytogenes } \\
\text { Listeria monocytogenes, Listeria innocua, Listeria ivanovii, Listeria seeligeri, Listeria grayi }\end{array}$ & $\begin{array}{l}\text { NE } \\
\text { NE } \\
\text { Epi } \\
\text { NE } \\
\text { Dopamine }\end{array}$ & $\begin{array}{l}\text { Freestone et al., 1999, 2000, } \\
\text { 2003, Freestone, } 2013 \\
\text { Coulanges et al., } 1997 \\
\text { Coulanges et al., } 1998\end{array}$ \\
\hline Staphylococcus aureus & $\begin{array}{l}\text { Epi } \\
\text { NE }\end{array}$ & Belay and Sonnenfeld, 2002 \\
\hline $\begin{array}{l}\text { Staphylococcus aureus, Staphylococcus epidermidis } \\
\text { Staphylococcus epidermidis } \\
\text { Streptococcus mutans, Streptococcus mitis, Streptococcus gordonii, Streptococcus } \\
\text { intermedius }\end{array}$ & $\begin{array}{l}\text { NE } \\
\text { NE } \\
\text { Epi } \\
\text { NE }\end{array}$ & $\begin{array}{l}\text { Mart'yanov et al., } 2021 \\
\text { Lyte et al., } 2003 \\
\text { Roberts et al., } 2002\end{array}$ \\
\hline
\end{tabular}

(Ratledge and Dover, 2000). The catechol core found in many siderophores is also present in the stress-related hormones of the catecholamine family. Thus, many studies which show the effect of catecholamines on bacterial growth, were carried out using a serum-like medium containing transferrin (Tf) and lactoferrin (Lf). This medium more appropriately mimics a stressful and bacteriostatic environment for the bacteria and would therefore more closely resemble the conditions that the bacteria might encounter within the host (Burton et al., 2002; Freestone et al., 2003; Lyte, 2004). Sandrini et al. (2010) showed that Epi, NE, and dopamine formed a complex with the ferric iron Fe (III) present in Tf and Lf. The catechol nucleus of catecholamines will then bind the iron sequestered by $\mathrm{Tf}$ and Lf, reducing their affinity with them. Thus, the presence of catecholamines would stimulate growth of bacteria by making the iron contained in Tf and Lf available for them. However, the exact mechanism by which iron is incorporated into the bacteria in the presence of catecholamines remains unclear. One study has implicated the porin proteins OmpA and $\mathrm{OmpC}$ from several enteropathogens in transferrin binding and transferrin dependent iron uptake (Sandrini et al., 2013). The authors showed that the presence of OmpA may increase 
growth of bacteria in the presence of some catecholamines. The assimilation of the siderophore/iron complex through specific Ton-B dependent receptors has also been suggested (Ratledge and Dover, 2000). For example, in P. aeruginosa, there are at least 34 Ton-B dependent or putative receptors, including those involved in the reuptake of pyoverdine and pyochelin, the two main siderophores (Cornelis and Bodilis, 2009), and it has been shown that in presence of NE, the expression of the genes coding for the synthesis of these siderophores are decreased (Li et al., 2009). Additionally, Perraud et al. (2020) demonstrated that catecholamine neurotransmitters (dopamine, L-DOPA, Epi, and NE) can act as siderophores, chelating iron and efficiently bringing it into $P$. aeruginosa cells via the PiuA and PirA TonB-dependent transporters (TBDTs). These authors found that PiuA exhibited more pronounced specificity for dopamine uptake than for NE, Epi, and L-DOPA, whereas PirA specificity appeared to be higher for L-DOPA and NE. Similar mechanisms were suggested in other Gram-negative bacteria. Indeed, in E. coli (Burton et al., 2002; Freestone et al., 2003) and Salmonella (Williams et al., 2006; Dichtl et al., 2019) siderophore synthesis and uptake systems appeared also to be integral elements in the mechanism by which stressrelated neuroendocrine hormone induce growth. Salmonella enterica produces enterochelin which bioavailability for bacterial iron acquisition is reduced by the mammalian siderocalin in addition to the affinity of enterochelin for lipid membranes. Salmonella glucosylation of enterochelin to salmochelin by IroB reduces both membrane affinity and siderocalin binding properties (Hantke et al., 2003). The increased bioavailability of salmochelin compared to enterochelin facilitates iron acquisition from transferrin to support pathogen growth. Due to their siderophore-like properties, Epi/NE accelerate bacterial iron acquisition and therefore can enhance pathogen growth in iron-limited environments. In Bordetella bronchiseptica, NE has been described to mediate acquisition of transferrin iron (Anderson and Armstrong, 2008; Armstrong et al., 2012). In Actinobacillus pleuropneumoniae, mutation of the gene encoding TonB2 protein prevents growth stimulation by catecholamines (Li et al., 2015), and in Aeromonas hydrophila, the increase of bacterial growth due to these molecules seems also dependent on TonB2-energy transduction system (Dong et al., 2016). Recently, Aldriwesh et al. (2019) showed that Epi and NE present in peritoneal dialysate can enhance the development of bacteria and the infection risk via transferrin iron provision. All these results showed that catecholamines can increase growth of several bacteria, and that this effect may be, in part, closely related to iron homeostasis.

\section{Effect of Catecholamines on Chemotaxis and Motility}

Chemotaxis is one way in which bacteria could react to the compounds present in their environment. It allows them to navigate in gradients of various chemicals in order to locate conditions that are beneficial for growth. Scarce studies are available on the effect of catecholamines on chemotaxis. Chet et al. (1973) have reported that the chemotactic response of
P. fluorescens was significantly enhanced by Epi. Later, using an agarose plug chemotaxis assay, Bansal et al. (2007) found that both Epi and NE were chemo-attractants for E. coli O157:H7. More recently, Lopes and Sourjik (2018) showed that E. coli RP437 reacts with mixed responses for dopamine and NE using FRET (Fluorescence Resonance Energy Transfer) and microfluidics assay. Indeed, both hormones elicited biphasic results. Dopamine was sensed as a repellent at concentrations below $1 \mathrm{mM}$ and as attractant at $10 \mathrm{mM}$. The response to NE had an inverse pattern. This molecule behaved as a weak attractant at low concentrations, but it produced a repellent response above $1 \mathrm{mM}$.

More data are available concerning catecholamines and motility tests (Table 3). These molecules have been found to enhance the motility of numerous bacteria, including pathogenic strains as $P$. fluorescens MFN1032 (Biaggini et al., 2015), P. aeruginosa PAO1/H103 (Cambronel et al., 2019), P. aeruginosa PA14 (Hegde et al., 2009), S. enterica serovar Typhimurium (Bearson and Bearson, 2008; Peterson et al., 2011), E. coli O157:H7 (Bansal et al., 2007), and some Campylobacter and Vibrio species (Cogan et al., 2007; Yang et al., 2021). In $V$. harveyi, the addition of the eukaryotic $\alpha$-adrenergic antagonist phentolamine, or the bacterial catecholamine receptor antagonist LED209, was able to neutralize NE-induced swimming motility (Yang Q. et al., 2014). These authors found also that the dopaminergic antagonist chlorpromazine and the LED209 antagonist reduced dopamine-induced motility of this bacterium. The motility of other Vibrio species (V. anguillarum, $V$. campbellii, $V$. parahaemolyticus) can also be modulated by catecholamines (Pande et al., 2014). Chlorpromazine was able to stop the effect of dopamine in $V$. anguillarum and $V$. campbellii, and the $\alpha$-adrenergic receptor antagonists phentolamine and phenoxybenzamine neutralized the effect of NE, whereas the $\beta$-adrenergic receptor antagonist propranolol had limited to no effect. This antagonist also failed to block the motility induced by NE in Yersinia ruckeri (Torabi Delshad et al., 2019). In V. parahaemolyticus, the bacterial antagonist LED209 neutralized the stimulatory effects of catecholamines on the growth and motility of the bacteria (Yang et al., 2021). In Burkholderia pseudomallei, phentolamine was found to reverse only partially the effect of Epi on motility (Intarak et al., 2014).

The expression of genes involved in flagellum formation and motility has been quantified in some bacteria exposed to catecholamines, and thus found to be modulated. Indeed, Yang Q. et al. (2014) showed that NE and Dopa significantly up-regulate the expression of ten genes involved in the flagella synthesis and chemotaxis of $V$. harveyi. The same result was observed for C. jejuni exposed to Epi and NE, in which many of the upregulated genes were involved in flagellar assembly pathway (Xu et al., 2015). Surprisingly, in P. aeruginosa PA14, a treatment with $50 \mu \mathrm{M} \mathrm{NE}$ was found to decrease the expression of motility genes, while at $500 \mu \mathrm{M}$, they were up-regulated (Hegde et al., 2009), showing the influence of the concentration of stress hormones on their effects.

Thus, the presence of Epi or NE has been shown in multiple investigations to significantly enhance the motility of bacteria. However, an impact on the transcription of genes of the flagellar 
or chemotaxis operons is not always apparent, probably due to the experimental conditions. In fact, gene expression assays are usually quantified using broth cultures whereas motility assays are typically performed using semi-solid agar medium. The differences in incubation conditions for growth rate and growth phase in broth and motility assays may account for a lack of congruence between transcriptional analysis and motility phenotype.

\section{Effect on Biofilm}

Biofilms are composed of cells bound to a surface and to each other and embedded within a matrix of extracellular polymeric substances they have produced (Donlan, 2002). For most of the microorganisms, the ability to form biofilms is a key factor to colonize and survive in the host environment (Costerton et al., 1999; Donlan and Costerton, 2002), promoting bacterial growth and pathogenicity (Parsek and Singh, 2003). Catecholamines were found to stimulate the biofilm in several bacteria (Table 4). First evidences of positive effect were obtained with utilization of the catecholamines inotropes, NE, and dobutamine, on S. epidermidis (Lyte et al., 2003). These authors found that incubation of this bacterium with catecholamines in the presence of human plasma resulted in a significant increase of growth and biofilm formation on both polystyrene and silicone surfaces, which was associated with extensive exopolysaccharide production. This suggested that the stimulation of bacterial proliferation and biofilm formation by these drugs may be an etiological factor in the development of intravascular catheter colonization and catheter-related infection. Since then, several other studies have shown an impact of catecholamines on adhesion and biofilm formation for various bacteria. Most of these experiments have also been conducted on abiotic surfaces. For example, Yang Q. et al. (2014) demonstrated that both $\mathrm{NE}$ and dopamine could increase the biofilm formation and exopolysaccharides production in $V$. harveyi, and this was blocked by the antagonists phentolamine, phenoxybenzamine, labetalol and LED209 for NE, chlorpromazine and LED209 for dopamine. Similarly, the biofilm formation of Y. ruckeri was found to be enhanced by NE and dopamine and antagonists were used to inhibit these effects (Torabi Delshad et al., 2019). In E. coli K-12 MC1000, addition of Epi/NE increased biofilm's thickness on polyvinyl chloride surface through the QseC sensor (Yang K. et al., 2014). Siderophores and ferric iron transport system also appear to play a vital role in the mechanism by which catecholamines influence biofilms formation (Feraco et al., 2016). In $P$. aeruginosa H103, a flow-cell device with glass surface was used to investigate the biofilm formation in dynamic conditions in the presence of Epi (Cambronel et al., 2019). The authors found no modification of the biofilm architecture with this catecholamine, but thicknesses and biovolume were significantly increased with $10 \mu \mathrm{M}$ Epi compared to the untreated biofilm. Interestingly, it has been demonstrated that catecholamines had

TABLE 3 | Bacterial motility and chemotaxis in presence of catecholamines.

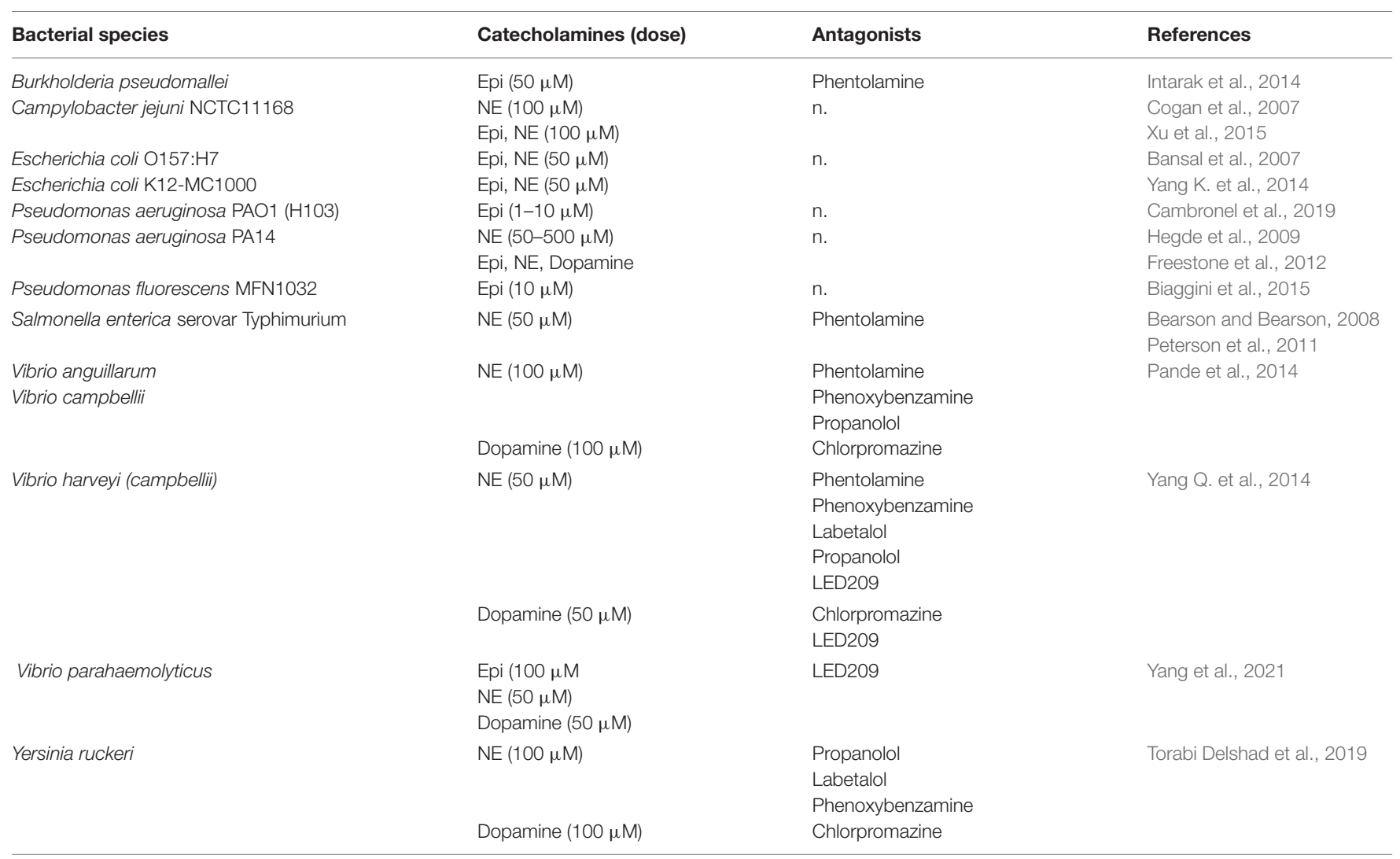

$n$, not used in the study. 
no impact on the growth of the Gram-positive Cutibacterium acnes, but were able to promote its biofilm formation (Borrel et al., 2019). Recently, the effect of catecholamines were also investigated in E. faecalis and the authors showed that Epi and NE can stimulate biofilm formation and adhesion of pathogenic but also probiotic strains of this species (Cambronel et al., 2020). On the contrary, the responses of S. lugdunensis, $S$. epidermidis, and $S$. aureus to Epi and dopamine were more variable, with increase or decrease of biofilm formation depending on the tested strains (Frank and Patel, 2008). Moreover, Epi and NE were found to promote the dispersion of biofilm in Mannheimia haemolytica (Pillai et al., 2018). Similarly, Lanter and Davies (2015) demonstrated that C. acnes biofilms were dispersed when challenged with $\mathrm{NE}$ in the presence of iron-bound transferrin or with free iron. Another study by Lanter et al. (2014) also showed that addition of NE (at $400 \mu \mathrm{M}$ ) induced dispersion of $P$. aeruginosa biofilms when grown under low iron conditions in the presence of transferrin. This dispersion is related to the release of degradation enzymes that can be harmful to the host tissue (Lanter et al., 2014).

The impact of catecholamines on mixed biofilms remains to be investigated in the future, to better understand the competition between bacteria in ecological niches. A recent publication explored for the first time the impact of NE on monospecies and dual-species biofilms of S. epidermidis and S. aureus (Mart'yanov et al., 2021). These authors showed that NE can affect the biofilm formation of both species with a strong dependence on aerobic

TABLE 4 | Bacterial biofilm in presence of catecholamines.

\begin{tabular}{|c|c|c|c|c|}
\hline Bacterial species & Catecholamines (dose) & Effects on biofilms & Antagonists & References \\
\hline Aeromonas hydrophila & $\begin{array}{l}\text { Epi }(100 \mu \mathrm{M}) \\
\text { NE }(100 \mu \mathrm{M}) \\
\text { Dopamine }(100 \mu \mathrm{M})\end{array}$ & $\begin{array}{l}\text { Increase } \\
\text { (Crystal violet staining) }\end{array}$ & $\mathrm{n}$. & Dong et al., 2016 \\
\hline Cutibacterium acnes & $\begin{array}{l}\text { Epi }(1 \mu \mathrm{M}) \\
\mathrm{NE}(1 \mu \mathrm{M})\end{array}$ & $\begin{array}{l}\text { Increase } \\
\text { (Crystal violet staining and CLSM analyses) }\end{array}$ & $\mathrm{n}$. & Borrel et al., 2019 \\
\hline Cutibacterium acnes VP1 & NE $(400 \mu \mathrm{M})$ & $\begin{array}{l}\text { Dispersion (Quantification of bacteria released from } \\
\text { biofilm) }\end{array}$ & $\mathrm{n}$. & $\begin{array}{l}\text { Lanter and } \\
\text { Davies, } 2015\end{array}$ \\
\hline Enterococcus faecalis & $\begin{array}{l}\text { Epi }(1-100 \mu \mathrm{M}) \\
\mathrm{NE}(1-100 \mu \mathrm{M})\end{array}$ & $\begin{array}{l}\text { Increase } \\
\text { (Crystal violet staining and CLSM analyses) }\end{array}$ & $\mathrm{n}$. & $\begin{array}{l}\text { Cambronel et al., } \\
2020\end{array}$ \\
\hline Escherichia coli K12-MC1000 & $\begin{array}{l}\text { Epi }(50 \mu \mathrm{M}) \\
\text { NE }(50 \mu \mathrm{M})\end{array}$ & $\begin{array}{l}\text { Biofilm increase } \\
\text { (Crystal violet staining, CLSM and SEM analyses) }\end{array}$ & $\mathrm{n}$. & $\begin{array}{l}\text { Yang K. et al., } \\
2014\end{array}$ \\
\hline Escherichia coli O157:H7 & $\begin{array}{l}\text { Epi }(50 \mu \mathrm{M}) \\
\mathrm{NE}(50 \mu \mathrm{M})\end{array}$ & $\begin{array}{l}\text { Biofilm increase } \\
\text { (Crystal violet staining, microarray) }\end{array}$ & $\mathrm{n}$. & $\begin{array}{l}\text { Bansal et al., } \\
2007\end{array}$ \\
\hline Mannheimia haemolytica & $\begin{array}{l}\text { Epi }(50 \mu \mathrm{M}) \\
\text { NE }(50 \mu \mathrm{M})\end{array}$ & $\begin{array}{l}\text { Dispersion } \\
\text { (Crystal violet staining, } \\
\text { CLSM and SEM analyses) }\end{array}$ & $\mathrm{n}$. & Pillai et al., 2018 \\
\hline Pseudomonas aeruginosa $\mathrm{H} 103$ & Epi $(1-10 \mu \mathrm{M})$ & $\begin{array}{l}\text { Increase } \\
\text { (CLSM analyses) }\end{array}$ & $\mathrm{n}$. & $\begin{array}{l}\text { Cambronel et al., } \\
2019\end{array}$ \\
\hline Pseudomonas aeruginosa PAO1 & NE $(400 \mu \mathrm{M})$ & $\begin{array}{l}\text { Dispersion (Quantification of bacteria released from } \\
\text { biofilm) }\end{array}$ & $\mathrm{n}$. & $\begin{array}{l}\text { Lanter et al., } \\
2014\end{array}$ \\
\hline Pseudomonas aeruginosa PA14 & $\begin{array}{l}\text { Epi }(5 \mu \mathrm{M}) \\
\text { NE }(5 \mu \mathrm{M}) \\
\text { Dopamine }(5 \mu \mathrm{M})\end{array}$ & $\begin{array}{l}\text { Increase } \\
\text { (Crystal violet staining, SEM analyses) }\end{array}$ & $\mathrm{n}$. & $\begin{array}{l}\text { Freestone et al., } \\
2012\end{array}$ \\
\hline Staphylococcus epidermidis & $\mathrm{NE}(100 \mu \mathrm{M})$ & $\begin{array}{l}\text { Increase } \\
\text { (SEM analyses) }\end{array}$ & $\mathrm{n}$. & Lyte et al., 2003 \\
\hline $\begin{array}{l}\text { Staphylococcus lugdunensis } \\
\text { Staphylococcus epidermidis } \\
\text { Staphylococcus aureus }\end{array}$ & $\begin{array}{l}\text { Epi }(0-50 \mu \mathrm{g} / \mathrm{mL}) \\
\text { Dopamine }(0-32 \mu \mathrm{g} / \mathrm{mL})\end{array}$ & $\begin{array}{l}\text { Increase or decrease } \\
\text { (Safranin staining and quantification) }\end{array}$ & $\mathrm{n}$. & $\begin{array}{l}\text { Frank and Patel, } \\
2008\end{array}$ \\
\hline $\begin{array}{l}\text { Staphylococcus aureus } \\
\text { Staphylococcus epidermidis } \\
\text { (dual species biofilm) }\end{array}$ & $\mathrm{NE}\left(10^{-7} \mathrm{M}\right)$ & Enumeration on Luria-Bertani agar plates & $\mathrm{n}$. & $\begin{array}{l}\text { Mart'yanov et al., } \\
2021\end{array}$ \\
\hline Vibrio harveyi (Campbellii) & $\begin{array}{l}\mathrm{NE}(50 \mu \mathrm{M}) \\
\text { Dopamine }(50 \mu \mathrm{M})\end{array}$ & $\begin{array}{l}\text { Increase } \\
\text { (Crystal violet staining) }\end{array}$ & $\begin{array}{l}\text { Phentolamine } \\
\text { LED209 } \\
\text { Phenoxybenzamine } \\
\text { Labetalol } \\
\text { Propranolol } \\
\text { Chlorpromazine }\end{array}$ & $\begin{array}{l}\text { Yang Q. et al., } \\
2014\end{array}$ \\
\hline Yersinia ruckeri & $\begin{array}{l}\mathrm{NE}(100 \mu \mathrm{M}) \\
\text { Dopamine }(100 \mu \mathrm{M})\end{array}$ & $\begin{array}{l}\text { Increase } \\
\text { (Crystal violet staining) }\end{array}$ & $\begin{array}{l}\text { Phenoxybenzamine } \\
\text { Labetalol } \\
\text { Propranolol } \\
\text { Chlorpromazine }\end{array}$ & $\begin{array}{l}\text { Torabi Delshad } \\
\text { et al., } 2019\end{array}$ \\
\hline
\end{tabular}

$n$, not used in the study; CLSM, confocal laser scanning microscope; SEM, scanning electron microscopy. 
or anaerobic culture conditions. They found that S. epidermidis suppresses $S$. aureus growth in dual-species biofilms and that $\mathrm{NE}$ can accelerate this process, contributing to the competitive behavior of staphylococci.

\section{Effect on Adhesion/Invasion, Cytotoxicity and Virulence}

Several studies have investigated the impact of catecholamines on the interaction between bacteria and eukaryotic cells (Table 5). $\mathrm{NE}$ or Epi were found to be able to stimulate the adhesion potential of bacteria (e.g., A. hydrophyla, Act. pleuropneumoniae, C. jejuni, E. faecalis, P. aeruginosa) on lung and intestinal cells. Conversely, a decrease of adhesion has been observed for Streptococcus pneumoniae on A549 lung cells when the bacteria were pre-treated with $\mathrm{NE}$ or incubated with cells in presence of NE (Gonzales et al., 2013). The cytotoxic activity of catecholamines have been studied in a porcine lung epithelial cell line (SJPL), infected by Act. pleuropneumoniae (Li et al., 2012), using a CytoTox $96 \mathrm{LDH}$ kit, and staining with crystal violet. Both methods showed that cytolytic activity was significantly increased by Epi but repressed by NE. The adrenergic receptor antagonists phentolamine and propanolol were found to be able to reverse significantly the effects of Epi and NE. In a study conducted by Biaggini et al. (2015), P. fluorescens treated with Epi led to $75 \%$ mortality of the undifferentiated Caco-2/TC7 cells, but the cytotoxicity of the untreated bacteria was almost the same with about $70 \%$ cell mortality. Nakano et al. (2007b) have shown that NE changed expression of TTSS1-related genes of $V$. parahaemolyticus and induced cytotoxic activity.

In Campylobacter, Cogan et al. (2007) examined invasion of Caco-2 cells with C. jejuni NCTC11168, and noticed that at least 10 times more bacteria were recovered within epithelial cells after $2 \mathrm{~h}$, when they were pretreated with NE. Later, in 2014, the same research group investigated the invasion of other Campylobacter strains in T84 epithelial cells, and they found that $C$. jejuni M1

TABLE 5 | In vitro bacterial effects in presence of catecholamines (adhesion/invasion, cytotoxicity).

\begin{tabular}{|c|c|c|c|c|c|}
\hline Bacterial species & Catecholamines (dose) & Cell lines & In vitro effects & Antagonists & References \\
\hline Aeromonas hydrophyla & $\begin{array}{l}\text { Epi }(100 \mu \mathrm{M}) \\
\text { NE }(100 \mu \mathrm{M}) \\
\text { Dopamine }(100 \mu \mathrm{M})\end{array}$ & $\begin{array}{l}\text { HEp-2 } \\
\text { epithelial cells }\end{array}$ & Increase of adhesion & n. & Dong et al., 2016 \\
\hline $\begin{array}{l}\text { Actinobacillus } \\
\text { pleuropneumoniae }\end{array}$ & $\begin{array}{l}\text { Epi }(50 \mu \mathrm{M}) \\
\mathrm{NE}(50 \mu \mathrm{M})\end{array}$ & $\begin{array}{l}\text { SJPL } \\
\text { lung cells }\end{array}$ & $\begin{array}{l}\text { Adhesion induced by NE but not by } \\
\text { Epi } \\
\text { Cytotoxicity enhanced by Epi but } \\
\text { repressed by NE }\end{array}$ & $\begin{array}{l}\text { Phentolamine } \\
\text { Propanolol }\end{array}$ & Li et al., 2012 \\
\hline \multirow[t]{2}{*}{$\begin{array}{l}\text { Campylobacter jejuni } \\
\text { NCTC11168 }\end{array}$} & $\mathrm{NE}(100 \mu \mathrm{M})$ & $\begin{array}{l}\text { Caco-2 intestinal } \\
\text { cells }\end{array}$ & $\begin{array}{l}\text { Increase of invasion } \\
\text { Decrease of TEER } \\
\text { Breakdown of tight junction } \\
\text { (occludin) observed by CLSM }\end{array}$ & n. & Cogan et al., 2007 \\
\hline & $\begin{array}{l}\text { Epi }(100 \mu \mathrm{M}) \\
\text { NE }(100 \mu \mathrm{M})\end{array}$ & $\begin{array}{l}\text { Caco-2 intestinal } \\
\text { cells }\end{array}$ & Increase of adhesion/invasion & $\mathrm{n}$. & Xu et al., 2015 \\
\hline Campylobacter species & $\mathrm{NE}(100 \mu \mathrm{M})$ & T84 epithelial cells & $\begin{array}{l}\text { Increase of invasion for } \\
\text { C. jejuni M1 and C. fetus fetus, not } \\
\text { for C. jejuni } 81116 \text { and C. coli } 1669 \\
\text { Decrease of TEER breakdown of } \\
\text { tight junction (occludin) observed } \\
\text { by CLSM }\end{array}$ & $\mathrm{n}$. & Aroori et al., 2014 \\
\hline Enterococcus faecalis & $\begin{array}{l}\text { Epi }(1 \mu \mathrm{M}) \\
\mathrm{NE}(1 \mu \mathrm{M})\end{array}$ & $\begin{array}{l}\text { Caco-2/TC7 } \\
\text { intestinal cells } \\
\text { HaCaT keratinocyte } \\
\text { cells }\end{array}$ & Increase of adhesion & $\mathrm{n}$. & $\begin{array}{l}\text { Cambronel et al., } \\
2020\end{array}$ \\
\hline $\begin{array}{l}\text { Salmonella enterica } \\
\text { serovar Typhimurium }\end{array}$ & $\mathrm{NE}(50 \mu \mathrm{M})$ & HeLa epithelial cells & Increase of invasion & $\mathrm{n}$. & $\begin{array}{l}\text { Moreira and } \\
\text { Sperandio, } 2012\end{array}$ \\
\hline $\begin{array}{l}\text { Streptococcus } \\
\text { pneumoniae }\end{array}$ & $\mathrm{NE}(50 \mu \mathrm{M})$ & A549 lung cells & Decrease of adhesion & $\mathrm{n}$. & $\begin{array}{l}\text { Gonzales et al., } \\
2013\end{array}$ \\
\hline $\begin{array}{l}\text { Pseudomonas } \\
\text { aeruginosa PAO1 }\end{array}$ & Epi (1 $\mu \mathrm{M})$ & $\begin{array}{l}\text { Caco-2/TC7 } \\
\text { intestinal cells }\end{array}$ & $\begin{array}{l}\text { Increase of adhesion/invasion and } \\
\text { translocation } \\
\text { Decrease in TEER }\end{array}$ & $\mathrm{n}$. & Biaggini, 2015 \\
\hline $\begin{array}{l}\text { Pseudomonas } \\
\text { aeruginosa PA14 }\end{array}$ & NE (50 and $500 \mu \mathrm{M})$ & $\begin{array}{l}\text { HCT-8 intestinal } \\
\text { cells }\end{array}$ & Increase of adhesion/invasion & $\mathrm{n}$. & Hegde et al., 2009 \\
\hline $\begin{array}{l}\text { Pseudomonas } \\
\text { fluorescens MFN1032 }\end{array}$ & Epi (1 $\mu \mathrm{M})$ & $\begin{array}{l}\text { Caco-2/TC7 } \\
\text { intestinal cells }\end{array}$ & $\begin{array}{l}\text { No effect on cytotoxicity } \\
\text { Decrease of TEER } \\
\text { F-actin cytoskeleton } \\
\text { disorganization (CLSM observation) }\end{array}$ & $\mathrm{n}$. & Biaggini et al., 2015 \\
\hline Vibrio parahaemolyticus & $\mathrm{NE}(50 \mu \mathrm{M})$ & $\begin{array}{l}\text { Caco-2 intestinal } \\
\text { cells }\end{array}$ & Increase of cytotoxicity & $\begin{array}{l}\text { Phentolamine } \\
\text { Propanonol }\end{array}$ & $\begin{array}{l}\text { Nakano et al., } \\
2007 b\end{array}$ \\
\hline
\end{tabular}

$n$, not used in the study; TEER, transepithelial electrical resistance; CLSM, confocal laser scanning microscope. 
TABLE 6 | In vivo bacterial effects in presence of catecholamines.

\begin{tabular}{|c|c|c|c|c|}
\hline Bacterial species & Catecholamines (dose) & In vivo effects & Antagonists & References \\
\hline \multirow[t]{2}{*}{ Aeromonas hydrophyla } & $\mathrm{NE}(1 \mathrm{mg} / 400 \mu \mathrm{L})$ & $\begin{array}{l}\text { NE enhances the systemic spread of the } \\
\text { bacteria during infection of mice }\end{array}$ & $\mathrm{n}$. & Dong et al., 2016 \\
\hline & NE $(100 \mu \mathrm{M})$ & Increased mortality of crucian carp & $\mathrm{n}$. & Gao et al., 2019 \\
\hline $\begin{array}{l}\text { Pseudomonas aeruginosa } \\
\mathrm{H} 103\end{array}$ & Epi $(1-10 \mu \mathrm{M})$ & $\begin{array}{l}\text { Increased mortality of Galleria mellonella } \\
\text { larvae (with } 10 \mu \mathrm{M} \text { Epi) }\end{array}$ & $\mathrm{n}$. & Cambronel et al., 2019 \\
\hline $\begin{array}{l}\text { Salmonella enterica serovar } \\
\text { Typhimurium }\end{array}$ & NE (200 mg/kg) & $\begin{array}{l}\text { Oral administration of } \mathrm{NE} \text {, but not preculture } \\
\text { with NE alters the course of infection in pigs }\end{array}$ & $\mathrm{n}$. & Pullinger et al., 2010 \\
\hline Vibrio campbelli BB120 & NE/Dopamine (100 $\mu \mathrm{M})$ & $\begin{array}{l}\text { Increased virulence toward giant freshwater } \\
\text { prawn larvae (Macrobrachium rosenbergii) }\end{array}$ & $\begin{array}{l}\text { Phentolamine } \\
\text { Chlorpromazine }\end{array}$ & Pande et al., 2014 \\
\hline Vibrio harveyi & NE/Dopamine $(50 \mu \mathrm{M})$ & $\begin{array}{l}\text { Increased virulence toward gnotobiotic } \\
\text { brine shrimp larvae }\end{array}$ & $\begin{array}{l}\text { Phentolamine } \\
\text { Phenoxybenzamine } \\
\text { Labetalol } \\
\text { LED209 } \\
\text { Chlorpromazine }\end{array}$ & Yang Q. et al., 2014 \\
\hline Yersinia ruckeri & NE/Dopamine (100 $\mu \mathrm{M})$ & Increased mortality of rainbow trout & $\begin{array}{l}\text { Phenoxybenzamine } \\
\text { Labetalol } \\
\text { Propanolol } \\
\text { Chlorpromazine }\end{array}$ & $\begin{array}{l}\text { Torabi Delshad et al., } \\
2019\end{array}$ \\
\hline
\end{tabular}

$n$, not used in the study.

and C. fetus subsp. fetus 10842 were also more invasive after $48 \mathrm{~h}$ pretreatment with $\mathrm{NE}$, contrary to the invasion potential of C. jejuni subsp. jejuni 81116 and C. coli 1669 that were not modified (Aroori et al., 2014). In this study, the authors also observed that the presence of $\mathrm{NE}$ enhanced the reduction of transepithelial resistance (TER) of T84 cells infected by C. jejuni M1, C. coli and C. fetus subsp. fetus 10842; and increased breakdown of tight junctions. Similarly, experiments performed on differentiated Caco-2/TC7 cells with $P$. aeruginosa PAO1 showed that a pre-treatment of this bacterium with Epi increased its invasive and translocation potential, and the reduction of TER (Biaggini, 2015). In Salmonella, the presence of $50 \mu \mathrm{M}$ Epi in a late log phase LB-culture enhanced by 1.5 -fold its invasion of HeLa cells, with an evident impact of QseC and QseE on the pathogenicity island 1 (SPI-1) upregulation (increase of $s o p B$ and sipA transcription by two-fold) that is involved in the invasion phenotype (Moreira and Sperandio, 2012). Similar effect was observed with $\mathrm{NE}$ in the same growth conditions, where invF and $\operatorname{sop} B$ encoded in SPI- 1 were increased by $>15$-fold. In contrast, Karavolos et al. (2008) indicated a downregulation of invF following $30 \mathrm{~min}$ of exposure to $50 \mu \mathrm{M}$ Epi in similar growth conditions.

Few in vivo experiments were also conducted by some researchers (Table 6). Pande et al. (2014) showed that $100 \mu \mathrm{M}$ dopamine and NE significantly increased the virulence of V. campbellii BB120 in a model of giant shrimp larvae. The survival of the larvae was found to be reduced by $15 \%$, after 6-8 days of infection with dopamine or NE-pretreated $V$. campbellii BB120, compared to infection with untreated bacteria. In this work, a dopaminergic receptor antagonist for dopamine (chlorpromazine) and an adrenergic receptor antagonist (phentolamine), were also tested. The authors found that chlorpromazine could not neutralize the effect of dopamine, whereas the adrenergic receptor antagonist phentolamine only neutralized the effect of $\mathrm{NE}$ at a relatively high concentration
$(500 \mu \mathrm{M})$ and in only 2 of the 3 trials. Similarly, in Y. ruckeri, these catecholamines (dopamine and NE) significantly enhanced the virulence towards rainbow trout, and some antagonists were able to neutralize the effect of the stress hormones (Torabi Delshad et al., 2019). Indeed, phenoxybenzamine (the $\alpha$-adrenergic antagonist) and labetolol (the $\alpha$ - and $\beta$-adrenergic antagonist) were able to block the increased virulence induced by NE, and chlorpromazine (the dopaminergic antagonist) could inhibit the effect of dopamine. On the contrary, propranolol did not show any antagonist ability to neutralize the effect of NE. In a mouse model, Dong et al. (2016) found that $\mathrm{NE}$ increased the proliferation capacity of $A$. hydrophila in the lungs. Initially administered in the intestine, the bacteria translocated through the gut and were able to disseminate into the lungs of mice. Another study conducted by Pullinger et al. (2010) found that NE augments Salmonella enterica-induced enteritis in pigs, in association with increased net replication but independent of the putative adrenergic sensor kinases QseC and QseE. Gao et al. (2019) found that the mortality of crucian carp challenged with A. hydrophila AH196 was significantly higher in the group treated with NE. In the same study, realtime PCR analyses revealed that NE notably up-regulated 13 out of 26 virulence-associated genes expression. Dowd (2007) reported that NE increased the expression levels of the shigatoxins coding-genes stx 1 and stx 2 of E. coli O157:H7 during the $5 \mathrm{~h}$ incubation.

\section{Other Effects}

Catecholamines have been found to be able to modulate the sensitivity/resistance to antibiotics. For example, it has been shown that catecholamines can help bacteria for better growth recovery following antibiotic treatment (Freestone et al., 2012). Indeed, when $P$. aeruginosa PA14 was exposed to subinhibitory concentrations of tobramycin in serum-SAPI medium, the authors showed that adding NE allowed the bacteria to 
have a better growth $\left(10^{3} \mathrm{CFU} / \mathrm{mL}\right.$ at $24 \mathrm{~h}$ versus $5.10^{5}$ $\mathrm{CFU} / \mathrm{mL}$ with $\mathrm{NE}$ ). This effect has also been observed in S. epidermidis (Freestone et al., 2016) and A. baumannii (Inaba et al., 2016). In C. jejuni, transcriptomic analysis showed that two genes involved in antimicrobial peptide resistance (Cj1583c and $\mathrm{Cj} 0193 \mathrm{c}$ ) were overexpressed in the presence of $100 \mu \mathrm{M}$ Epi or NE (Xu et al., 2015). On the contrary, in S. enterica serovar Typhimurium, Epi reduced the ability of the bacteria to survive polymyxin B treatment (Karavolos et al., 2008). Using microarray analysis, the authors observed a decrease in the expression of the pmr regulon ( $p m r H F I J K L M$, responsible for polymyxin resistance), which was mediated by the BasSR two component signal transduction system. This phenotype was reversed by the addition of the $\beta$-adrenergic blocker propranolol. Given that PmrAB activation was observed in the presence of extracellular iron for prevention of iron toxicity (Wösten et al., 2000), the binding of iron by Epi may partly explain the decreased expression of the PmrAB regulon. Karavolos et al. (2008) also showed that Epi increased oxidative stress resistance in S. enterica serovar Typhimurium when the bacterium was exposed to the molecule. Indeed, using transcriptomic assay and a luminescent transcriptional reporter, the authors found that the superoxide dismutase $\operatorname{sod} A$ gene was significantly upregulated by Epi. Similarly, Intarak et al. (2014) found that Epi-treated Burkholderia pseudomallei exhibited increased resistance to superoxide, consistent with induction of $\operatorname{sodB}$ expression.

Besides those effects, catecholamines may also regulate the production of some metabolites. At the human oral microbiome, production of volatile sulfur compounds, the major gasses responsible for bad breath (mainly hydrogen sulfide $\mathrm{H}_{2} \mathrm{~S}$ ) was observed in periodontal pathogenic bacteria (i.e., Fusobacterium nucleatum, Porphyromonas endodontalis, Prevotella intermedia, and Porphyromonas) exposed to catecholamines (Roberts et al., 2002; Calil et al., 2014; de Lima et al., 2018).

Horizontal gene transfer (HGT) in bacteria is another mechanism impacted by host signals with an enhanced conjugative gene transfer observed between enteric bacteria (Peterson et al., 2011). Exposure to $5 \mu \mathrm{M} N E$ in LB medium stimulated the transfer of a conjugative plasmid encoding multidrug resistance from a clinical $S$. Typhimurium strain to a recipient $E$. coli strain. Interestingly, a significant up-regulation of tra gene expression involved with plasmid transfer was observed. Treatment with the adrenergic receptor antagonists (phentolamine at $500 \mu \mathrm{M}$ ) negated the NEenhanced conjugation frequency to baseline levels. Thus, these mediators of host stress may influence the evolution and adaptation of pathogens in the environment due to the transfer of genes that encode resistance to antibiotics and virulence factors.

\section{Meta-Effects Studied by Transcriptomic/Proteomic Analyses}

The global effects of catecholamines on bacteria have been first studied on a luxS enterohemorrhagic E. coli (EHEC) mutant by Kendall et al. (2007) using $50 \mu \mathrm{M}$ of Epi and GeneChip microarrays (Affymetric system) for transcriptome analysis (Table 7). The authors observed a differential expression for 5,204 genes. In fact, Epi mainly increased the expression of the LEE regulon, which is known to play a pivotal role in EHEC virulence. The activated genes included the LEE genes, the flagellar regulon genes, the genes encoding iron uptake systems, the gene encoding the Hfq protein (a chaperone involved in small regulatory RNA post-transcriptional regulation), and genes encoding several nucleoid proteins, all reported to be involved in LEE regulation.

Another publication reported the global effects of Epi in S. enterica serovar Typhimurium (Karavolos et al., 2008). In this work, the transcriptomic analyses showed that approximately $0.6 \%$ of the transcriptome of the pathogen was significantly regulated by $50 \mu \mathrm{M}$ Epi. The major feature of this bacterial adrenaline response was the upregulation of genes involved in metal homeostasis and oxidative stress. The key metal transport systems were induced within $30 \mathrm{~min}$ of treatment. Alterations in genes encoding proteins of unknown functions and changes in levels of regulators and signal transduction genes were also noticed.

Hegde et al. (2009) analyzed the transcriptome of $P$. aeruginosa PA14 exposed to 50 and $500 \mu \mathrm{M}$ NE for $7 \mathrm{~h}$.

TABLE 7 | Meta-effects of catecholamines on bacteria studied by transcriptomic analysis.

\begin{tabular}{|c|c|c|c|}
\hline Bacterial species & Catecholamines (dose) & Meta-effects & References \\
\hline $\begin{array}{l}\text { Actinobacillus } \\
\text { pleuropneumoniae }\end{array}$ & $\begin{array}{l}\text { Epi }(50 \mu \mathrm{M}) \\
\text { NE }(100 \mu \mathrm{M})\end{array}$ & $\begin{array}{l}\text { Differential expression of } 158 \text { and } 105 \text { genes, for Epi and NE, respectively. Many } \\
\text { virulence factors. Only } 18 \text { genes regulated by both hormones }\end{array}$ & Li et al., 2012 \\
\hline $\begin{array}{l}\text { luxS Escherichia coli EHEC } \\
\text { mutant }\end{array}$ & Epi (50 $\mu \mathrm{M})$ & $\begin{array}{l}\text { Differential expression of 5,204 genes. Increased expression of the locus of } \\
\text { enterocyte effacement (LEE), flagellar regulon genes, iron uptake systems }\end{array}$ & Kendall et al., 2007 \\
\hline $\begin{array}{l}\text { Salmonella enterica serovar } \\
\text { Typhimurium }\end{array}$ & Epi $(50 \mu M)$ & $\begin{array}{l}\text { Modulation of } 0.6 \% \text { of the transcriptome. Upregulation of genes involved in metal } \\
\text { homeostasis and oxidative stress }\end{array}$ & $\begin{array}{l}\text { Karavolos et al., } \\
2008\end{array}$ \\
\hline $\begin{array}{l}\text { Pseudomonas aeruginosa } \\
\text { PA14 }\end{array}$ & NE $(50-500 \mu \mathrm{M})$ & $\begin{array}{l}\text { Exposure to } 50 \mu \mathrm{M} \text { NE altered the expression of } 184 \text { genes (128 induced, } 56 \\
\text { repressed) } \\
\text { Exposure to } 500 \mu \mathrm{M} \text { NE induced } 287 \text { genes and repressed } 50 \text { genes. } \\
\text { Up-regulation of virulence with } 500 \mu \mathrm{M} \text { NE but not } 50\end{array}$ & Hegde et al., 2009 \\
\hline $\begin{array}{l}\text { Campylobacter jejuni } \\
\text { NCTC11168 }\end{array}$ & $\begin{array}{l}\text { Epi }(100 \mu \mathrm{M}) \\
\text { NE }(100 \mu \mathrm{M})\end{array}$ & $\begin{array}{l}\text { Differential expression of } 183 \text { and } 156 \text { genes, for Epi and NE, respectively. } 102 \text { of } \\
\text { these modulated genes were common for the two hormones } \\
\text { (iron uptake, motility, virulence, oxidative stress response, nitrosative stress } \\
\text { tolerance, enzyme metabolism, DNA repair and metabolism, ribosomal protein } \\
\text { biosynthesis) }\end{array}$ & Xu et al., 2015 \\
\hline
\end{tabular}


They found that $500 \mu \mathrm{M}$ but not $50 \mu \mathrm{M}$ of this molecule upregulated the genes involved in the regulation of the virulence determinants pyocyanin, elastase, and the Pseudomonas quinolone signal (PQS, 2-heptyl-3-hydroxy-4-quinolone).

Genome-wide $\mathrm{MudJ}$ transposon mutagenesis was used to study Epi- and NE-regulated genes in S. Typhimurium (Spencer et al., 2010). A transposon library of 10,000 S. Typhimurium mutants was screened and led to the identification of seven down-regulated and one up-regulated fusions in the presence of $250 \mu \mathrm{M}$ Epi. The down-regulated genes included two virulence-related genes virK and mig14 (involved in bacterial resistance to antimicrobial peptides), in addition to iroC (ABC transporter), accC (Acetyl-CoA carboxylase subunit), $n r d F$ (Ribonucleotide diphosphate reductase subunit), yedP (Putative mannosyl-3-phosphoglycerate phosphatase), and STM3081 (Putative 1-lactate/malate dehydrogenase), while the yhaK gene was up-regulated whose product is a putative cytoplasmic protein of unknown function. The regulation of virK, mig14 and yhaK by $500 \mu \mathrm{M}$ Epi and NE could be reversed in a promoter-luciferase fusion assay by addition of an $\alpha$-adrenergic antagonist (phentolamine at $500 \mu \mathrm{M}$ ). In addition, exposure to $500 \mu \mathrm{M}$ Epi or NE significantly increased sensitivity of S. Typhimurium to the antimicrobial peptide cathelicidin LL-37. Interestingly, a significant increase in sensitivity to LL37 was demonstrated for the virK mutant in the absence of catecholamines.

Later, Li et al. (2012) investigated the global effects of catecholamines on Act. pleuropneumoniae, an important porcine respiratory pathogen causing significant economic loss in the global pig industry. Gene expression profiles after Epi and NE treatment were compared with untreated bacteria. The microarray results showed that 158 and 105 genes were differentially expressed in the presence of Epi and NE, respectively. These genes were assigned to various functional categories including many virulence factors, whereas only 18 genes were regulated by both catecholamines. Thus, differential regulation of gene expression suggests that this pathogen may have multiple responsive systems for the two hormones.

Transcriptomic analyses using Agilent microarrays were then performed in C. jejuni NCTC 11168, cultivated in iron-restricted medium, and supplemented with Epi and NE (Xu et al., 2015). The authors found that Epi and NE respectively modified the expression of 183 and 156 genes, compared to the expression in absence of these hormones, and 102 of these modulated genes were common for Epi and NE treatments. Various cellular functions were found to be modified, including iron uptake, motility, virulence, oxidative stress response, nitrosative stress tolerance, enzyme metabolism, DNA repair and metabolism, and ribosomal protein biosynthesis.

At the time of writing this review, only two proteomic analyses on the effect of catecholamines on bacteria were retrieved. The first study was done by Toulouse et al. (2019). The authors investigated the impact of Epi and adrenochrome on $V$. cholerae. They observed a proteome change in proteins involved in iron homeostasis, metabolism, signaling or translational and transcriptional control. The second study was conducted by Scardaci et al. (2021) using the probiotic strain Enterococcus faecium NCIMB10415. Combining a gelfree/label-free proteomic analysis, these authors evaluated the global changes induced by NE treatment in the bacterium. They found that exposure of E. faecium NCIMB10415 to this bioactive molecule enhanced the abundance of proteins related to stress response and to host-microbe interaction, such as moonlight proteins involved in adhesion and immune stimulation.

All these meta-effects showed that catecholamines can modulate several functions in bacteria, but it is important to notice that the results obtained may depend on the hormone (Epi or NE), their concentrations, and the medium used for the bacterial growth.

\section{CONCLUSION AND FUTURE PROSPECT}

Thirty years of studies in the field of microbial endocrinology have shown that there are multiple bi-directional interactions between bacteria and their host. In such interactions, the main actors are neurotransmitters whose mission is the transmission of information within and between living cells, giving the interkingdom signaling. As for the genetic code shared by all living organisms, a common class of mediator-type molecules indicates that the mechanism of communication within neurotransmitters appears to be widely recognized. The role of regulatory proteins in catecholamines sensing is an area of growing research. Though evidence exists that catecholamines exert effects on bacteria within in vitro culture conditions (i.e., growth, motility, adhesion, virulence). However, these effects are mainly dependent on media composition and inoculum density (growth phase), being most prominent in a minimal salt's medium (i.e., serum-SAPI) miming nutrient poor and iron-limited conditions encountered in vivo. The variability of results obtained in the literature concerning catecholamines can also be due to a poor stability of the molecules in solution as they need to be freshly prepared before the experiments.

Within the human microbiome, the ability of microorganisms to respond to the panoply of neuroendocrine hormones is becoming increasingly recognized as playing a pivotal role in disease pathogenesis and maintenance of homeostasis (Lyte, 2013). In the near future, new methodologies as organ-onchip will be a promising sophisticated tool to investigate the interactions between bacteria and the host in the presence of several metabolites and molecules including hormones. This state of art technology will ensure a stable and/or variable dynamic flow of catecholamines, on bacteria and eukaryotic cells, and thus simulates more accurately what can happen in vivo, especially in case of a stress peak.

During their evolution, pathogenic bacteria can adapt and develop sophisticated systems allowing them to sense eukaryotic signals and to use them to their advantage to stimulate their colonization and virulence. While several data indicate that Gram-negative bacterial pathogens possess elements that specifically interact with catecholamines allowing them to sense the host environment, scarce data is available on such elements found in Gram-positive bacteria and especially in probiotic 
bacteria. A better knowledge of these systems will allow to decipher how stress hormones could be involved in the colonization by microbiota and in the eubiosis/dysbiosis of the gut or other organs. This may help to develop new treatments with medical and economic interest.

\section{REFERENCES}

Ahlquist, R. P. (1948). A study of the adrenotropic receptors. Am. J. Physiol. 153, 586-600. doi: 10.1152/ajplegacy.1948.153.3.586

Akula, R., and Mukherjee, S. (2020). New insights on neurotransmitters signaling mechanisms in plants. Plant Signal. Behav. 15:1737450. doi: 10.1080/15592324. 2020.1737450

Aldriwesh, M., Al-Dayan, N., Barratt, J., and Freestone, P. (2019). The iron biology status of peritoneal dialysis patients may be a risk factor for development of infectious peritonitis. Perit. Dial. Int. 39, 362-374. doi: 10.3747/pdi.2018.00 052

Anderson, M. T., and Armstrong, S. K. (2008). Norepinephrine mediates acquisition of transferrin-iron in Bordetella bronchiseptica. J. Bacteriol. 190, 3940-3947. doi: 10.1128/jb.00086-08

Andreis, D. T., and Singer, M. (2016). Catecholamines for inflammatory shock: a Jekyll-and-Hyde conundrum. Intens. Care Med. 42, 1387-1397. doi: 10.1007/ s00134-016-4249-z

Armstrong, S. K., Brickman, T. J., and Suhadolc, R. J. (2012). Involvement of multiple distinct Bordetella receptor proteins in the utilization of iron liberated from transferrin by host catecholamine stress hormones. Mol. Microbiol. 84, 446-462. doi: 10.1111/j.1365-2958.2012.08032.x

Aroori, S. V., Cogan, T. A., and Humphrey, T. J. (2014). Effect of noradrenaline on the virulence properties of Campylobacter species. Int. J. Microbiol. 2014:279075. doi: 10.1155/2014/279075

Bansal, T., Englert, D., Lee, J., Hegde, M., Wood, T. K., and Jayaraman, A. (2007). Differential effects of epinephrine, norepinephrine, and indole on Escherichia coli O157:H7 chemotaxis, colonization, and gene expression. Infect. Immun. 75, 4597-4607. doi: 10.1128/iai.00630-07

Bearson, B. L., and Bearson, S. M. (2008). The role of the QseC quorumsensing sensor kinase in colonization and norepinephrine-enhanced motility of Salmonella enterica serovar Typhimurium. Microb. Pathog. 44, 271-278. doi: 10.1016/j.micpath.2007.10.001

Bearson, B. L., Bearson, S. M., Uthe, J. J., Dowd, S. E., Houghton, J. O., Lee, I., et al. (2008). Iron regulated genes of Salmonella enterica serovar Typhimurium in response to norepinephrine and the requirement of fepDGC for norepinephrine-enhanced growth. Microbes Infect. 10, 807-816. doi: 10 . 1016/j.micinf.2008.04.011

Belay, T., and Sonnenfeld, G. (2002). Differential effects of catecholamines on in vitro growth of pathogenic bacteria. Life Sci. 71, 447-456. doi: 10.1016/s00243205(02)01683-1

Bergquist, J., Tarkowski, A., Ewing, A., and Ekman, R. (1998). Catecholaminergic suppression of immunocompetent cells. Immunol. Today 19, 562-567. doi: 10.1016/s0167-5699(98)01367-x

Berthelsen, S., and Pettinger, W. A. (1977). A functional basis for classification of alpha-adrenergic receptors. Life Sci. 21, 595-606. doi: 10.1016/0024-3205(77) 90066-2

Biaggini, K. (2015). Etude du dialogue système entéro-endocrinien/microbiote intestinal. Ph.D. thesis. Saint-Étienne-du-Rouvray: Université de Rouen.

Biaggini, K., Barbey, C., Borrel, V., Feuilloley, M., Dechelotte, P., and Connil, N. (2015). The pathogenic potential of Pseudomonas fluorescens MFN1032 on enterocytes can be modulated by serotonin, substance P and epinephrine. Arch. Microbiol. 197, 983-990. doi: 10.1007/s00203-015-1135-y

Bönisch, H., Bryan, L. J., Henseling, M., O'donnell, S. R., Stockmann, P., and Trendelenburg, U. (1985). The effect of various ions on uptake2 of catecholamines. Naunyn Schmiedebergs Arch. Pharmacol. 328, 407-416. doi: 10.1007/bf00692909

Borrel, V., Thomas, P., Catovic, C., Racine, P. J., Konto-Ghiorghi, Y., Lefeuvre, L., et al. (2019). Acne and Stress: impact of Catecholamines on Cutibacterium acnes. Front. Med. 6:155. doi: 10.3389/fmed.2019.00155

\section{AUTHOR CONTRIBUTIONS}

NC supervised the project of the review. All authors participated in the redaction of the manuscript and accepted the final version.

Burton, C. L., Chhabra, S. R., Swift, S., Baldwin, T. J., Withers, H., Hill, S. J., et al. (2002). The growth response of Escherichia coli to neurotransmitters and related catecholamine drugs requires a functional enterobactin biosynthesis and uptake system. Infect. Immun. 70, 5913-5923. doi: 10.1128/iai.70.11.5913-5923. 2002

Bylund, D. B. (1988). Subtypes of alpha 2-adrenoceptors: pharmacological and molecular biological evidence converge. Trends Pharmacol. Sci. 9, 356-361. doi: 10.1016/0165-6147(88)90254-4

Calil, C. M., Oliveira, G. M., Cogo, K., Pereira, A. C., Marcondes, F. K., and Groppo, F. C. (2014). Effects of stress hormones on the production of volatile sulfur compounds by periodontopathogenic bacteria. Braz. Oral Res. 28:S1806-S83242014000100228. doi: 10.1590/1807-3107bor-2014.vol28. 0008

Cambronel, M., Nilly, F., Mesguida, O., Boukerb, A. M., Racine, P. J., Baccouri, O., et al. (2020). Influence of Catecholamines (Epinephrine/Norepinephrine) on Biofilm Formation and Adhesion in Pathogenic and Probiotic Strains of Enterococcus faecalis. Front. Microbiol. 11:1501. doi: 10.3389/fmicb.2020. 01501

Cambronel, M., Tortuel, D., Biaggini, K., Maillot, O., Taupin, L., Rehel, K., et al. (2019). Epinephrine affects motility, and increases adhesion, biofilm and virulence of Pseudomonas aeruginosa H103. Sci. Rep. 9:20203. doi: 10.1038/ s41598-019-56666-7

Carlsson, A. (1987). Perspectives on the discovery of central monoaminergic neurotransmission. Annu. Rev. Neurosci. 10, 19-40. doi: 10.1146/annurev.ne. 10.030187.000315

Chet, I., Henis, Y., and Mitchell, R. (1973). Effect of biogenic amines and cannabinoids on bacterial chemotaxis. J. Bacteriol. 115, 1215-1218. doi: 10. 1128/jb.115.3.1215-1218.1973

Clarke, M. B., and Sperandio, V. (2005a). Transcriptional autoregulation by quorum sensing Escherichia coli regulators B and C (QseBC) in enterohaemorrhagic E. coli (EHEC). Mol. Microbiol. 58, 441-455. doi: 10.1111/ j.1365-2958.2005.04819.x

Clarke, M. B., and Sperandio, V. (2005b). Transcriptional regulation of $f l h \mathrm{DC}$ by QseBC and sigma (FliA) in enterohaemorrhagic Escherichia coli. Mol. Microbiol. 57, 1734-1749. doi: 10.1111/j.1365-2958.2005.04792.x

Clarke, M. B., Hughes, D. T., Zhu, C., Boedeker, E. C., and Sperandio, V. (2006) The QseC sensor kinase: a bacterial adrenergic receptor. Proc. Natl. Acad. Sci. U.S.A. 103, 10420-10425. doi: 10.1073/pnas.0604343103

Cogan, T. A., Thomas, A. O., Rees, L. E., Taylor, A. H., Jepson, M. A., Williams, P. H., et al. (2007). Norepinephrine increases the pathogenic potential of Campylobacter jejuni. Gut 56, 1060-1065. doi: 10.1136/gut.2006.114926

Cooper, E. V. (1946). Gas-gangrene following injection of adrenaline. Lancet 1, 459-461. doi: 10.1016/s0140-6736(46)91431-6

Cornelis, P., and Bodilis, J. (2009). A survey of TonB-dependent receptors in fluorescent pseudomonads. Environ. Microbiol. Rep. 1, 256-262. doi: 10.1111/ j.1758-2229.2009.00041.x

Costerton, J. W., Stewart, P. S., and Greenberg, E. P. (1999). Bacterial biofilms: common cause of persistent infections. Science 284, 1318-1322. doi: 10.1126/ science.284.5418.1318

Coulanges, V., Andre, P., and Vidon, D. J. (1998). Effect of siderophores, catecholamines, and catechol compounds on Listeria spp. Growth in ironcomplexed medium. Biochem. Biophys. Res. Commun. 249, 526-530. doi: 10. 1006/bbrc.1998.9184

Coulanges, V., Andre, P., Ziegler, O., Buchheit, L., and Vidon, D. J. (1997). Utilization of iron-catecholamine complexes involving ferric reductase activity in Listeria monocytogenes. Infect. Immun. 65, 2778-2785. doi: 10.1128/iai.65.7. 2778-2785.1997

Curtis, M. M., Russell, R., Moreira, C. G., Adebesin, A. M., Wang, C., Williams, N. S., et al. (2014). QseC inhibitors as an antivirulence approach for Gramnegative pathogens. mBio 5:e02165-14. doi: 10.1128/mBio.02165-14 
Cuvas Apan, O., Apan, T. Z., and Apan, A. (2016). In vitro antimicrobial activity of commonly used vasoactive drugs. J. Clin. Anesth. 34, 407-411. doi: 10.1016/ j.jclinane.2016.05.008

Dahlin, A., Xia, L., Kong, W., Hevner, R., and Wang, J. (2007). Expression and immunolocalization of the plasma membrane monoamine transporter in the brain. Neuroscience 146, 1193-1211. doi: 10.1016/j.neuroscience.2007.01.072

de Lima, P. O., Nani, B. D., Almeida, B., Marcondes, F. K., Groppo, F. C., de Moraes, A. B. A., et al. (2018). Stress-related salivary proteins affect the production of volatile sulfur compounds by oral bacteria. Oral Dis. 24, 1358-1366. doi: 10.1111/odi.12890

Dichtl, S., Demetz, E., Haschka, D., Tymoszuk, P., Petzer, V., Nairz, M., et al. (2019). Dopamine is a siderophore-like iron chelator that promotes Salmonella enterica Serovar Typhimurium virulence in mice. mBio 10:e02624-18. doi: 10.1128/mBio.02624- 18

Dixon, R. A., Kobilka, B. K., Strader, D. J., Benovic, J. L., Dohlman, H. G., Frielle, T., et al. (1986). Cloning of the gene and cDNA for mammalian beta-adrenergic receptor and homology with rhodopsin. Nature 321, 75-79. doi: 10.1038/ 321075a0

Dong, Y., Liu, J., Pang, M., Du, H., Wang, N., Awan, F., et al. (2016). Catecholamine-Stimulated Growth of Aeromonas hydrophila Requires the TonB2 Energy Transduction System but Is Independent of the Amonabactin Siderophore. Front. Cell. Infect. Microbiol. 6:183. doi: 10.3389/fcimb.2016. 00183

Donlan, R. M. (2002). Biofilms: microbial life on surfaces. Emerg. Infect. Dis. 8, 881-890. doi: 10.3201/eid0809.020063

Donlan, R. M., and Costerton, J. W. (2002). Biofilms: survival mechanisms of clinically relevant microorganisms. Clin. Microbiol. Rev. 15, 167-193. doi: $10.1128 / \mathrm{cmr} \cdot 15.2 .167-193.2002$

Dowd, S. E. (2007). Escherichia coli O157:H7 gene expression in the presence of catecholamine norepinephrine. FEMS Microbiol. Lett. 273, 214-223. doi: 10.1111/j.1574-6968.2007.00800.x

Duan, H., and Wang, J. (2010). Selective transport of monoamine neurotransmitters by human plasma membrane monoamine transporter and organic cation transporter 3. J. Pharmacol. Exp. Ther. 335, 743-753. doi: 10.1124/jpet.110.170142

Eisenhofer, G. (2001). The role of neuronal and extraneuronal plasma membrane transporters in the inactivation of peripheral catecholamines. Pharmacol. Ther. 91, 35-62. doi: 10.1016/s0163-7258(01)00144-9

Ellermann, M., and Sperandio, V. (2020). Bacterial signaling as an antimicrobial target. Curr. Opin. Microbiol. 57, 78-86. doi: 10.1016/j.mib.2020.08.001

Emorine, L. J., Marullo, S., Briend-Sutren, M. M., Patey, G., Tate, K., DelavierKlutchko, C., et al. (1989). Molecular characterization of the human beta 3-adrenergic receptor. Science 245, 1118-1121. doi: 10.1126/science.2570461

Engel, K., and Wang, J. (2005). Interaction of organic cations with a newly identified plasma membrane monoamine transporter. Mol. Pharmacol. 68, 1397-1407. doi: 10.1124/mol.105.016832

Engel, K., Zhou, M., and Wang, J. (2004). Identification and characterization of a novel monoamine transporter in the human brain. J. Biol. Chem. 279, 50042-50049. doi: 10.1074/jbc.m407913200

Felten, S. Y., and Olschowka, J. (1987). Noradrenergic sympathetic innervation of the spleen: II. Tyrosine hydroxylase (TH)-positive nerve terminals form synapticlike contacts on lymphocytes in the splenic white pulp. J. Neurosci. Res. 18, 37-48. doi: 10.1002/jnr.490180108

Feraco, D., Blaha, M., Khan, S., Green, J. M., and Plotkin, B. J. (2016). Host environmental signals and effects on biofilm formation. Microb. Pathog. 99, 253-263. doi: 10.1016/j.micpath.2016.08.015

Ford, A. P., Williams, T. J., Blue, D. R., and Clarke, D. E. (1994). Alpha 1adrenoceptor classification: sharpening Occam's razor. Trends Pharmacol. Sci. 15, 167-170. doi: 10.1016/0165-6147(94)90136-8

Frank, K. L., and Patel, R. (2008). Intravenously administered pharmaceuticals impact biofilm formation and detachment of Staphylococcus lugdunensis and other staphylococci. Diagn. Microbiol. Infect. Dis. 60, 9-16. doi: 10.1016/j. diagmicrobio.2007.07.008

Freestone, P. (2013). Communication between Bacteria and Their Hosts. Scientifica 2013:361073. doi: $10.1155 / 2013 / 361073$

Freestone, P. P. E., Al-Dayan, N., and Lyte, M. (2016). Staphylococci, Catecholamine Inotropes and Hospital-Acquired Infections. Adv. Exp. Med. Biol. 874, 183-199. doi: 10.1007/978-3-319-20215-0_8
Freestone, P. P., Haigh, R. D., Williams, P. H., and Lyte, M. (1999). Stimulation of bacterial growth by heat-stable, norepinephrine-induced autoinducers. FEMS Microbiol. Lett. 172, 53-60. doi: 10.1111/j.1574-6968.1999. tb13449. $\mathrm{x}$

Freestone, P. P., Haigh, R. D., Williams, P. H., and Lyte, M. (2003). Involvement of enterobactin in norepinephrine-mediated iron supply from transferrin to enterohaemorrhagic Escherichia coli. FEMS Microbiol. Lett. 222, 39-43. doi: 10.1016/s0378-1097(03)00243-x

Freestone, P. P., Hirst, R. A., Sandrini, S. M., Sharaff, F., Fry, H., Hyman, S., et al. (2012). Pseudomonas aeruginosa-catecholamine inotrope interactions: a contributory factor in the development of ventilator-associated pneumonia? Chest 142, 1200-1210. doi: 10.1378/chest.11-2614

Freestone, P. P., Lyte, M., Neal, C. P., Maggs, A. F., Haigh, R. D., and Williams, P. H. (2000). The mammalian neuroendocrine hormone norepinephrine supplies iron for bacterial growth in the presence of transferrin or lactoferrin. J. Bacteriol. 182, 6091-6098. doi: 10.1128/JB.182.21.6091-6098.2000

Freestone, P. P., Sandrini, S. M., Haigh, R. D., and Lyte, M. (2008). Microbial endocrinology: how stress influences susceptibility to infection. Trends Microbiol. 16, 55-64. doi: 10.1016/j.tim.2007.11.005

Ganz, T., and Nemeth, E. (2015). Iron homeostasis in host defence and inflammation. Nat. Rev. Immunol. 15, 500-510. doi: 10.1038/nri3863

Gao, J., Xi, B., Chen, K., Song, R., Qin, T., Xie, J., et al. (2019). The stress hormone norepinephrine increases the growth and virulence of Aeromonas hydrophila. Microbiologyopen 8:e0664. doi: 10.1002/mbo3.664

Gonzales, X. F., Castillo-Rojas, G., Castillo-Rodal, A. I., Tuomanen, E., and LópezVidal, Y. (2013). Catecholamine norepinephrine diminishes lung epithelial cell adhesion of Streptococcus pneumoniae by binding iron. Microbiology 159, 2333-2341. doi: 10.1099/mic.0.065607-0

Greengard, P. (2001). The neurobiology of dopamine signaling. Biosci. Rep. 21, 247-269. doi: 10.1023/a:1013205230142

Gründemann, D., Schechinger, B., Rappold, G. A., and Schomig, E. (1998). Molecular identification of the corticosterone-sensitive extraneuronal catecholamine transporter. Nat. Neurosci. 1, 349-351. doi: 10.1038/1557

Guckes, K. R., Kostakioti, M., Breland, E. J., Gu, A. P., Shaffer, C. L., Martinez, C. R. III, et al. (2013). Strong cross-system interactions drive the activation of the QseB response regulator in the absence of its cognate sensor. Proc. Natl. Acad. Sci. U.S.A. 110, 16592-16597. doi: 10.1073/pnas.1315320110

Hadjifrangiskou, M., Kostakioti, M., Chen, S. L., Henderson, J. P., Greene, S. E., and Hultgren, S. J. (2011). A central metabolic circuit controlled by QseC in pathogenic Escherichia coli. Mol. Microbiol. 80, 1516-1529. doi: 10.1111/j.13652958.2011.07660.x

Halang, P., Toulouse, C., Geißel, B., Michel, B., Flauger, B., Müller, M., et al. (2015). Response of Vibrio cholerae to the catecholamine hormones epinephrine and norepinephrine. J. Bacteriol. 197, 3769-3778. doi: 10.1128/JB.00345-15

Hantke, K., Nicholson, G., Rabsch, W., and Winkelmann, G. (2003). Salmochelins, siderophores of Salmonella enterica and uropathogenic Escherichia coli strains, are recognized by the outer membrane receptor IroN. Proc. Natl. Acad. Sci. U.S.A. 100, 3677-3682. doi: 10.1073/pnas.0737682100

Hegde, M., Wood, T. K., and Jayaraman, A. (2009). The neuroendocrine hormone norepinephrine increases Pseudomonas aeruginosa PA14 virulence through the las quorum-sensing pathway. Appl. Microbiol. Biotechnol. 84, 763-776. doi: 10.1007/s00253-009-2045-1

Hendley, E. D., Taylor, K. M., and Snyder, S. H. (1970). 3H-normetanephrine uptake in rat brain slices. Relationship to extraneuronal accumulation of norepinephrine. Eur. J. Pharmacol. 12, 167-179. doi: 10.1016/0014-2999(70) 90062-2

Hieble, J. P., Bondinell, W. E., and Ruffolo, R. R. Jr. (1995). Alpha- and beta-adrenoceptors: from the gene to the clinic. 1. Molecular biology and adrenoceptor subclassification. J. Med. Chem. 38, 3415-3444. doi: 10.1021/ jm00018a001

Hughes, D. T., Clarke, M. B., Yamamoto, K., Rasko, D. A., and Sperandio, V. (2009). The QseC adrenergic signaling cascade in Enterohemorrhagic E. coli (EHEC). PLoS Pathog. 5:e1000553. doi: 10.1371/journal.ppat.1000553

Inaba, M., Matsuda, N., Banno, H., Jin, W., Wachino, J. I., Yamada, K., et al. (2016). In vitro reduction of antibacterial activity of tigecycline against multidrug-resistant Acinetobacter baumannii with host stress hormone norepinephrine. Int. J. Antimicrob. Agents 48, 680-689. doi: 10.1016/j. ijantimicag.2016.09.022 
Intarak, N., Muangsombut, V., Vattanaviboon, P., Stevens, M. P., and Korbsrisate, S. (2014). Growth, motility and resistance to oxidative stress of the melioidosis pathogen Burkholderia pseudomallei are enhanced by epinephrine. Pathog. Dis. 72, 24-31. doi: 10.1111/2049-632x.12181

Iversen, L. L. (1971). Role of transmitter uptake mechanisms in synaptic neurotransmission. Br. J. Pharmacol. 41, 571-591. doi: 10.1111/j.1476-5381. 1971.tb07066.x

Karavolos, M. H., Bulmer, D. M., Spencer, H., Rampioni, G., Schmalen, I., Baker, S., et al. (2011). Salmonella Typhi sense host neuroendocrine stress hormones and release the toxin haemolysin E. EMBO Rep. 12, 252-258. doi: 10.1038/embor. 2011.4

Karavolos, M. H., Spencer, H., Bulmer, D. M., Thompson, A., Winzer, K., Williams, P., et al. (2008). Adrenaline modulates the global transcriptional profile of Salmonella revealing a role in the antimicrobial peptide and oxidative stress resistance responses. BMC Genomics 9:458. doi: 10.1186/1471-2164-9-458

Kendall, M. M., Rasko, D. A., and Sperandio, V. (2007). Global effects of the cell-to-cell signaling molecules autoinducer-2, autoinducer-3, and epinephrine in a luxS mutant of enterohemorrhagic Escherichia coli. Infect. Immun. 75, 4875-4884. doi: 10.1128/iai.00550-07

Kesici, S., Demirci, M., and Kesici, U. (2019). Antibacterial effects of lidocaine and adrenaline. Int. Wound J. 16, 1190-1194. doi: 10.1111/iwj.13182

Kim, C. S., Gatsios, A., Cuesta, S., Lam, Y. C., Wei, Z., Chen, H., et al. (2020). Characterization of Autoinducer-3 Structure and Biosynthesis in E. coli. ACS Cent. Sci. 6, 197-206. doi: 10.1021/acscentsci.9b01076

Kostakioti, M., Hadjifrangiskou, M., Pinkner, J. S., and Hultgren, S. J. (2009). QseC-mediated dephosphorylation of QseB is required for expression of genes associated with virulence in uropathogenic Escherichia coli. Mol. Microbiol. 73, 1020-1031. doi: 10.1111/j.1365-2958.2009.06826.x

Lands, A. M., Arnold, A., Mcauliff, J. P., Luduena, F. P., and Brown, T. G. Jr. (1967a). Differentiation of receptor systems activated by sympathomimetic amines. Nature 214, 597-598. doi: 10.1038/214597a0

Lands, A. M., Luduena, F. P., and Buzzo, H. J. (1967b). Differentiation of receptors responsive to isoproterenol. Life Sci. 6, 2241-2249. doi: 10.1016/0024-3205(67) 90031-8

Lanter, B. B., and Davies, D. G. (2015). Propionibacterium acnes recovered from atherosclerotic human carotid arteries undergoes biofilm dispersion and releases lipolytic and proteolytic enzymes in response to norepinephrine challenge in vitro. Infect. Immun. 83, 3960-3971. doi: 10.1128/iai. 00510-15

Lanter, B. B., Sauer, K., and Davies, D. G. (2014). Bacteria present in carotid arterial plaques are found as biofilm deposits which may contribute to enhanced risk of plaque rupture. mBio 5:e1206-14. doi: 10.1128/mBio.01206-14

Lewis, P. (1976). The essential action of propranolol in hypertension. Am. J. Med. 60, 837-852. doi: 10.1016/0002-9343(76)90904-9

Li, L., Chen, Z., Bei, W., Su, Z., Huang, Q., Zhang, L., et al. (2015). Catecholamines promote Actinobacillus pleuropneumoniae growth by regulating iron metabolism. PLoS One 10:e0121887. doi: 10.1371/journal.pone.0121887

Li, L., Xu, Z., Zhou, Y., Sun, L., Liu, Z., Chen, H., et al. (2012). Global effects of catecholamines on Actinobacillus pleuropneumoniae gene expression. PLoS One 7:e31121. doi: 10.1371/journal.pone.0031121

Li, W., Lyte, M., Freestone, P. P., Ajmal, A., Colmer-Hamood, J. A., and Hamood, A. N. (2009). Norepinephrine represses the expression of toxA and the siderophore genes in Pseudomonas aeruginosa. FEMS Microbiol. Lett. 299, 100-109. doi: 10.1111/j.1574-6968.2009.01739.x

Lopes, J. G., and Sourjik, V. (2018). Chemotaxis of Escherichia coli to major hormones and polyamines present in human gut. ISME J. 12, 2736-2747. doi: 10.1038/s41396-018-0227-5

Lymperopoulos, A., Rengo, G., Zincarelli, C., Soltys, S., and Koch, W. J. (2008). Modulation of adrenal catecholamine secretion by in vivo gene transfer and manipulation of $\mathrm{G}$ protein-coupled receptor kinase-2 activity. Mol. Ther. 16, 302-307. doi: 10.1038/sj.mt.6300371

Lyte, M. (2004). Microbial endocrinology and infectious disease in the 21st century. Trends Microbiol. 12, 14-20. doi: 10.1016/j.tim.2003.11.004

Lyte, M. (2013). Microbial endocrinology in the microbiome-gut-brain axis: how bacterial production and utilization of neurochemicals influence behavior. PLoS Pathog. 9:e1003726. doi: 10.1371/journal.ppat.1003726

Lyte, M. (2014). Microbial endocrinology and the microbiota-gut-brain axis. $A d v$. Exp. Med. Biol. 817, 3-24. doi: 10.1007/978-1-4939-0897-4_1
Lyte, M., and Brown, D. R. (2018). Evidence for PMAT- and OCT-like biogenic amine transporters in a probiotic strain of Lactobacillus: implications for interkingdom communication within the microbiota-gut-brain axis. PLoS One 13:e0191037. doi: 10.1371/journal.pone.0191037

Lyte, M., and Ernst, S. (1992). Catecholamine induced growth of gram negative bacteria. Life Sci. 50, 203-212. doi: 10.1016/0024-3205(92)90273-r

Lyte, M., Freestone, P. P., Neal, C. P., Olson, B. A., Haigh, R. D., Bayston, R., et al. (2003). Stimulation of Staphylococcus epidermidis growth and biofilm formation by catecholamine inotropes. Lancet 361, 130-135. doi: 10.1016/s0140-6736(03) 12231-3

Marinissen, M. J., and Gutkind, J. S. (2001). G-protein-coupled receptors and signaling networks: emerging paradigms. Trends Pharmacol. Sci. 22, 368-376. doi: 10.1016/s0165-6147(00)01678-3

Mart'yanov, S. V., Botchkova, E. A., Plakunov, V. K., and Gannesen, A. V. (2021). The impact of norepinephrine on mono-species and dualspecies Staphylococcal biofilms. Microorganisms 9:820. doi: 10.3390/ microorganisms 9040820

Mietzner, T. A., and Morse, S. A. (1994). The role of iron-binding proteins in the survival of pathogenic bacteria. Annu. Rev. Nutr. 14, 471-493. doi: 10.1146/ annurev.nu.14.070194.002351

Moreira, C. G., and Sperandio, V. (2012). Interplay between the QseC and QseE bacterial adrenergic sensor kinases in Salmonella enterica serovar Typhimurium pathogenesis. Infect. Immun. 80, 4344-4353. doi: 10.1128/iai. 00803-12

Moreira, C. G., Weinshenker, D., and Sperandio, V. (2010). QseC mediates Salmonella enterica serovar Typhimurium virulence in vitro and in vivo. Infect. Immun. 78, 914-926. doi: 10.1128/iai.01038-09

Moron, J. A., Brockington, A., Wise, R. A., Rocha, B. A., and Hope, B. T. (2002). Dopamine uptake through the norepinephrine transporter in brain regions with low levels of the dopamine transporter: evidence from knockout mouse lines. J. Neurosci. 22, 389-395. doi: 10.1523/jneurosci.22-02-00389. 2002

Nakano, M., Takahashi, A., Sakai, Y., Kawano, M., Harada, N., Mawatari, K., et al. (2007a). Catecholamine-induced stimulation of growth in Vibrio species. Lett. Appl. Microbiol. 44, 649-653. doi: 10.1111/j.1472-765x.2007.02136.x

Nakano, M., Takahashi, A., Sakai, Y., and Nakaya, Y. (2007b). Modulation of pathogenicity with norepinephrine related to the type III secretion system of Vibrio parahaemolyticus. J. Infect. Dis. 195, 1353-1360. doi: 10.1086/51 3275

Pande, G. S., Suong, N. T., Bossier, P., and Defoirdt, T. (2014). The catecholamine stress hormones norepinephrine and dopamine increase the virulence of pathogenic Vibrio anguillarum and Vibrio campbellii. FEMS Microbiol. Ecol. 90, 761-769. doi: 10.1111/1574-6941.12432

Parsek, M. R., and Singh, P. K. (2003). Bacterial biofilms: an emerging link to disease pathogenesis. Annu. Rev. Microbiol. 57, 677-701. doi: 10.1146/annurev. micro.57.030502.090720

Perez, D. M. (2006). The Adrenergic Receptors in the 21st Century. (Totowa, NJ: Humana Press), 129-134.

Perraud, Q., Cantero, P., Roche, B., Gasser, V., Normant, V. P., Kuhn, L., et al. (2020). Phenotypic adaption of Pseudomonas aeruginosa by hacking siderophores produced by other microorganisms. Mol. Cell. Proteomics 19, 589-607. doi: 10.1074/mcp.ra119.001829

Peterson, G., Kumar, A., Gart, E., and Narayanan, S. (2011). Catecholamines increase conjugative gene transfer between enteric bacteria. Microb. Pathog. 51, 1-8. doi: 10.1016/j.micpath.2011.03.002

Pillai, D. K., Cha, E., and Mosier, D. (2018). Role of the stress-associated chemicals norepinephrine, epinephrine and substance $\mathrm{P}$ in dispersal of Mannheimia haemolytica from biofilms. Vet. Microbiol. 215, 11-17. doi: 10.1016/j.vetmic. 2017.11.025

Pullinger, G. D., Van Diemen, P. M., Carnell, S. C., Davies, H., Lyte, M., and Stevens, M. P. (2010). 6-hydroxydopamine-mediated release of norepinephrine increases faecal excretion of Salmonella enterica serovar Typhimurium in pigs. Vet. Res. 41:68. doi: 10.1051/vetres/2010040

Rasko, D. A., Moreira, C. G., Li De, R., Reading, N. C., Ritchie, J. M., Waldor, M. K., et al. (2008). Targeting QseC signaling and virulence for antibiotic development. Science 321, 1078-1080. doi: 10.1126/science.1160354

Ratledge, C., and Dover, L. G. (2000). Iron metabolism in pathogenic bacteria. Annu. Rev. Microbiol. 54, 881-941. doi: 10.1146/annurev.micro.54.1.881 
Reading, N. C., Rasko, D. A., Torres, A. G., and Sperandio, V. (2009). The twocomponent system QseEF and the membrane protein QseG link adrenergic and stress sensing to bacterial pathogenesis. Proc. Natl. Acad. Sci. U.S.A. 106, 5889-5894. doi: 10.1073/pnas.0811409106

Reading, N. C., Torres, A. G., Kendall, M. M., Hughes, D. T., Yamamoto, K., and Sperandio, V. (2007). A novel two-component signaling system that activates transcription of an enterohemorrhagic Escherichia coli effector involved in remodeling of host actin. J. Bacteriol. 189, 2468-2476. doi: 10.1128/jb.01848-06

Reiske, L., Schmucker, S. S., Steuber, J., Toulouse, C., Pfaffinger, B., and Stefanski, V. (2020). Interkingdom cross-talk in times of stress: Salmonella Typhimurium grown in the presence of catecholamines inhibits porcine immune functionality in vitro. Front. Immunol. 11:572056. doi: 10.3389/fimmu.2020.572056

Renaud, M., and Miget, A. (1930). Role favorisant des perturbations locales causees par l'adrenaline sur le developpement des infections microbiennes. CR Seances Soc. Biol. Fil. 103, 1052-1054.

Roberts, A., Matthews, J. B., Socransky, S. S., Freestone, P. P., Williams, P. H., and Chapple, I. L. (2002). Stress and the periodontal diseases: effects of catecholamines on the growth of periodontal bacteria in vitro. Oral Microbiol. Immunol. 17, 296-303. doi: 10.1034/j.1399-302x.2002.170506.x

Rosenbaum, D. M., Rasmussen, S. G., and Kobilka, B. K. (2009). The structure and function of G-protein-coupled receptors. Nature 459, 356-363. doi: 10.1038/ nature 08144

Sandrini, S. M., Shergill, R., Woodward, J., Muralikuttan, R., Haigh, R. D., Lyte, M., et al. (2010). Elucidation of the mechanism by which catecholamine stress hormones liberate iron from the innate immune defense proteins transferrin and lactoferrin. J. Bacteriol. 192, 587-594. doi: 10.1128/jb.01028-09

Sandrini, S., Masania, R., Zia, F., Haigh, R., and Freestone, P. (2013). Role of porin proteins in acquisition of transferrin iron by enteropathogens. Microbiology 159, 2639-2650. doi: 10.1099/mic.0.071928-0

Scardaci, R., Varese, F., Manfredi, M., Marengo, E., Mazzoli, R., and Pessione, E. (2021). Enterococcus faecium NCIMB10415 responds to norepinephrine by altering protein profiles and phenotypic characters. J. Proteomics 231:104003. doi: $10.1016 /$ j.jprot.2020.104003

Sharaff, F., and Freestone, P. (2011). Microbial endocrinology. Cent. Eur. J. Biol. 6:685. doi: 10.2478/s11535-011-0067-z

Sharma, V. K., and Casey, T. A. (2014a). Determining the relative contribution and hierarchy of hha and $q s e \mathrm{BC}$ in the regulation of flagellar motility of Escherichia coli O157:H7. PLoS One 9:e85866. doi: 10.1371/journal.pone.008 5866

Sharma, V. K., and Casey, T. A. (2014b). Escherichia coli O157:H7 lacking the qseBC-encoded quorum-sensing system outcompetes the parental strain in colonization of cattle intestines. Appl. Environ. Microbiol. 80, 882-892. doi: 10.1128/AEM.03198-13

Sharon, G., Sampson, T. R., Geschwind, D. H., and Mazmanian, S. K. (2016). The central nervous system and the gut microbiome. Cell 167, 915-932. doi: 10.1016/j.cell.2016.10.027

Sora, I., Hall, F. S., Andrews, A. M., Itokawa, M., Li, X. F., Wei, H. B., et al. (2001). Molecular mechanisms of cocaine reward: combined dopamine and serotonin transporter knockouts eliminate cocaine place preference. Proc. Natl. Acad. Sci. U.S.A. 98, 5300-5305. doi: 10.1073/pnas.091039298

Spencer, H., Karavolos, M. H., Bulmer, D. M., Aldridge, P., Chhabra, S. R., Winzer, K., et al. (2010). Genome-wide transposon mutagenesis identifies a role for host neuroendocrine stress hormones in regulating the expression of virulence genes in Salmonella. J. Bacteriol. 192, 714-724. doi: 10.1128/jb.01329-09

Sperandio, V., Torres, A. G., Jarvis, B., Nataro, J. P., and Kaper, J. B. (2003). Bacteria-host communication: the language of hormones. Proc. Natl. Acad. Sci. U.S.A. 100, 8951-8956. doi: 10.1073/pnas. 1537100100

Strosberg, A. D. (1993). Structure, function, and regulation of adrenergic receptors. Protein Sci. 2, 1198-1209. doi: 10.1002/pro.5560020802

Torabi Delshad, S., Soltanian, S., Sharifiyazdi, H., and Bossier, P. (2019). Effect of catecholamine stress hormones (dopamine and norepinephrine) on growth, swimming motility, biofilm formation and virulence factors of Yersinia ruckeri in vitro and an in vivo evaluation in rainbow trout. J. Fish Dis. 42, 477-487. doi: $10.1111 /$ jfd.12934
Toulouse, C., Schmucker, S., Metesch, K., Pfannstiel, J., Michel, B., Starke, I., et al. (2019). Mechanism and impact of catecholamine conversion by Vibrio cholerae. Biochim. Biophys. Acta Bioenerg. 1860, 478-487. doi: 10.1016/j.bbabio.2019.04. 003

Vialou, V., Balasse, L., Dumas, S., Giros, B., and Gautron, S. (2007). Neurochemical characterization of pathways expressing plasma membrane monoamine transporter in the rat brain. Neuroscience 144, 616-622. doi: 10.1016/j. neuroscience.2006.09.058

Wayment, H. K., Schenk, J. O., and Sorg, B. A. (2001). Characterization of extracellular dopamine clearance in the medial prefrontal cortex: role of monoamine uptake and monoamine oxidase inhibition. J. Neurosci. 21, 35-44. doi: 10.1523/jneurosci.21-01-00035.2001

Williams, P. H., Rabsch, W., Methner, U., Voigt, W., Tschape, H., and Reissbrodt, R. (2006). Catecholate receptor proteins in Salmonella enterica: role in virulence and implications for vaccine development. Vaccine 24, 3840-3844. doi: 10. 1016/j.vaccine.2005.07.020

Wilson, V. G., Grohmann, M., and Trendelenburg, U. (1988). The uptake and $\mathrm{O}$-methylation of $3 \mathrm{H}-(+/-)$-isoprenaline in rat cerebral cortex slices. Naunyn Schmiedebergs Arch. Pharmacol. 337, 397-405. doi: 10.1007/BF00169530

Wösten, M. M., Kox, L. F., Chamnongpol, S., Soncini, F. C., and Groisman, E. A. (2000). A signal transduction system that responds to extracellular iron. Cell 103, 113-125. doi: 10.1016/s0092-8674(00)00092-1

Xu, F., Wu, C., Guo, F., Cui, G., Zeng, X., Yang, B., et al. (2015). Transcriptomic analysis of Campylobacter jejuni NCTC 11168 in response to epinephrine and norepinephrine. Front. Microbiol. 6:452. doi: 10.3389/fmicb.2015.00452

Yamashita, A., Singh, S. K., Kawate, T., Jin, Y., and Gouaux, E. (2005). Crystal structure of a bacterial homologue of $\mathrm{Na}^{+} / \mathrm{Cl}^{-}$dependent neurotransmitter transporters. Nature 437, 215-223. doi: 10.1038/nature03978

Yang, K., Meng, J., Huang, Y. C., Ye, L. H., Li, G. J., Huang, J., et al. (2014). The role of the QseC quorum-sensing sensor kinase in epinephrine-enhanced motility and biofilm formation by Escherichia coli. Cell Biochem. Biophys. 70, 391-398. doi: 10.1007/s12013-014-9924-5

Yang, Q., Anh, N. D., Bossier, P., and Defoirdt, T. (2014). Norepinephrine and dopamine increase motility, biofilm formation, and virulence of Vibrio harveyi. Front. Microbiol. 5:584. doi: 10.3389/fmicb.2014.00584

Yang, Q., Zou, P., Cao, Z., Wang, Q., Fu, S., Xie, G., et al. (2021). QseC Inhibition as a Novel Antivirulence Strategy for the Prevention of Acute Hepatopancreatic Necrosis Disease (AHPND)-Causing Vibrio parahaemolyticus. Front. Cell. Infect. Microbiol. 10:5946. doi: 10.3389/fcimb.2020.594652

Yernool, D., Boudker, O., Jin, Y., and Gouaux, E. (2004). Structure of a glutamate transporter homologue from Pyrococcus horikoshii. Nature 431, 811-818. doi: 10.1038/nature03018

Zhou, M., Hank Simms, H., and Wang, P. (2004). Increased gut-derived norepinephrine release in sepsis: up-regulation of intestinal tyrosine hydroxylase. Biochim. Biophys. Acta 1689, 212-218. doi: 10.1016/j.bbadis. 2004.03.008

Conflict of Interest: The authors declare that the research was conducted in the absence of any commercial or financial relationships that could be construed as a potential conflict of interest.

Publisher's Note: All claims expressed in this article are solely those of the authors and do not necessarily represent those of their affiliated organizations, or those of the publisher, the editors and the reviewers. Any product that may be evaluated in this article, or claim that may be made by its manufacturer, is not guaranteed or endorsed by the publisher.

Copyright (® 2021 Boukerb, Cambronel, Rodrigues, Mesguida, Knowlton, Feuilloley, Zommiti and Connil. This is an open-access article distributed under the terms of the Creative Commons Attribution License (CC BY). The use, distribution or reproduction in other forums is permitted, provided the original author(s) and the copyright owner(s) are credited and that the original publication in this journal is cited, in accordance with accepted academic practice. No use, distribution or reproduction is permitted which does not comply with these terms. 